Review

\title{
Calcium: The Missing Link in Auxin Action
}

\section{Steffen Vanneste ${ }^{1, *}$ and Jiří Friml ${ }^{1,2}$}

1 Plant Systems Biology, VIB, and Plant Biotechnology and Bio-informatics, Ghent University, Ghent 9052, Belgium

2 Institute of Science and Technology Austria (IST Austria), Klosterneuburg 3400, Austria

* Author to whom correspondence should be addressed; E-Mail: stnes@psb.vib-ugent.be; Tel.: +32-9-33-13943; Fax: +32-9-33-13809.

Received: 5 August 2013; in revised form: 7 October 2013 / Accepted: 10 October 2013/ Published: 21 October 2013

\begin{abstract}
Due to their sessile lifestyles, plants need to deal with the limitations and stresses imposed by the changing environment. Plants cope with these by a remarkable developmental flexibility, which is embedded in their strategy to survive. Plants can adjust their size, shape and number of organs, bend according to gravity and light, and regenerate tissues that were damaged, utilizing a coordinating, intercellular signal, the plant hormone, auxin. Another versatile signal is the cation, $\mathrm{Ca}^{2+}$, which is a crucial second messenger for many rapid cellular processes during responses to a wide range of endogenous and environmental signals, such as hormones, light, drought stress and others. Auxin is a good candidate for one of these $\mathrm{Ca}^{2+}$-activating signals. However, the role of auxin-induced $\mathrm{Ca}^{2+}$ signaling is poorly understood. Here, we will provide an overview of possible developmental and physiological roles, as well as mechanisms underlying the interconnection of $\mathrm{Ca}^{2+}$ and auxin signaling.
\end{abstract}

Keywords: auxin; calcium; signal transduction; auxin transport

\section{Auxin and $\mathrm{Ca}^{2+}$ : Essential Elements of Plant Development}

How do you survive when you are sessile? The answer is that you need to be extremely flexible and even change your body plan according to actual limitations imposed by the environment. Herein lays the key to the success of plants. They can develop highly complex and elaborate body plans under optimal conditions, while less favorable environments results in much smaller plants with reduced 
body plan complexity. The ability to adjust the number and size of organs, regenerate damaged or destroyed organs and to (re)orient growth according to light and gravity are a few examples of the mechanisms that illustrate plants' flexible, adaptive growth.

At the very core of this developmental flexibility is the plant hormone auxin [1-3]. Several decades of intensive research have revealed that this plant hormone is involved in nearly every aspect of plant development, ranging from embryogenesis and multiple steps of organogenetic processes in the root (lateral root initiation, morphogenesis and outgrowth, stem cell niche maintenance) $[4,5]$ and shoot (phyllotaxis [6], leaf initiation [7], leaf morphogenesis [8], vascular patterning [9], ovule patterning [10]), but is also involved in apical hook formation [11,12], gravitropism [13], hydrotropism [14], phototropism [15-17], shade avoidance [18], root hair formation [19,20], stomatal opening [21], pollen development [22], senescence [23,24], fruit development [25,26], leaf abscission [27], response to pathogens [28,29] and abiotic stress [30]. At the cellular level, this is reflected in control over cell differentiation [31], cell cycle regulation [32-34], cellular morphogenesis (e.g., leaf pavement cells) [35] and membrane trafficking [36-39]. Because of auxin's pleiotropic morphogenetic capacities, plants have elaborate mechanisms to prevent unwanted/unnecessary auxin activity. Together, regulation of biosynthesis, conjugation, subcellular compartmentalization, degradation and active transport act to control the cellular auxin levels [40,41]. Additional fine-tuning of auxin's action is achieved by modulation of the signal transduction pathway(s) [42,43]. Via one or more of these control mechanisms, a myriad of endogenous (developmental and hormonal) and exogenous signals (stresses, nutrient availability, etc.) impact on auxin's action, thereby optimizing the plant's growth and development [44].

The divalent cation, $\mathrm{Ca}^{2+}$, is one of the most universal second messengers; a signal that relays a primary signal, such as derived from an activated receptor, from the surface of the cell to intracellular targets. It can be found in ancient bacteria and throughout eukaryotic lineages, where it is essential to support life $[45,46]$. The importance and pleiotropism of $\mathrm{Ca}^{2+}$ in cellular signaling processes is roughly summarized in the famous quote from Otto Loewi in 1959: "Ja Kalzium, das ist alles!" (Yes, calcium is everything!). Furthermore, in plants, $\mathrm{Ca}^{2+}$ is a fundamentally important second messenger, as demonstrated by its involvement in a multitude of essential cellular process, ranging from cell division, cell growth/shrinkage, secretion, transcriptional regulation, cellular polarity, etc., by which it impacts on stomatal aperture regulation, responses to light, responses to biotic and abiotic stresses, immunity a and responses to multiple plant hormones, including response to auxin [47-49]. Because $\mathrm{Ca}^{2+}$ signals can be regulated by so many different cues and have such a broad impact on cellular processes, it is not unlikely that $\mathrm{Ca}^{2+}$ acts to integrate multiple cues in a single output. Here, we will focus on the effects of auxin on $\mathrm{Ca}^{2+}$ and vice versa.

\section{The Source of Auxin-Induced $\mathrm{Ca}^{2+}$ Signals}

Via $\mathrm{Ca}^{2+}$ sensitive dyes and, recently, also genetically encoded $\mathrm{Ca}^{2+}$ sensors, strong correlations could be observed between $\mathrm{Ca}^{2+}$ and auxin signaling. This is most apparent after exogenous application of synthetic and natural auxins, which induce a rapid, transient increase in cytosolic $\mathrm{Ca}^{2+}$ concentration in wheat leaf protoplasts [50,51], maize coleoptile and root cells [52-54], parsley hypocotyl segments [53], intact Arabidopsis roots [55] and closed orchid guard cells [21]. In nearly all 
cases, the increase of cytosolic $\mathrm{Ca}^{2+}$ concentration was observed to occur within minutes after auxin application, demonstrating that auxin is a potent inducer of $\mathrm{Ca}^{2+}$ signals. One of the important questions that remain to be answered is how these auxin-induced $\mathrm{Ca}^{2+}$ signals are generated. Generally, rapid and local $\mathrm{Ca}^{2+}$ signals generated in the cytosol depend on a $\mathrm{Ca}^{2+}$ current that is driven by a steep concentration gradient between the cytosol (nanomolar range) and its adjacent organelles or extracellular space (millimolar range). This allows the bringing about of a rapid and strong $\mathrm{Ca}^{2+}$ rise in the cytosol required for immediate activation of an appropriate response by the simple opening of a few $\mathrm{Ca}^{2+}$ channels $[45,46,56]$.

In plants, the apoplast, the vacuole, the endoplasmic reticulum and all smaller organelles could serve as sources for auxin-induced $\mathrm{Ca}^{2+}$. The apoplast is an important source for auxin-induced $\mathrm{Ca}^{2+}$ signals. These could be prevented by application of membrane impermeable $\mathrm{Ca}^{2+}$ chelators and $\mathrm{Ca}^{2+}$ channel inhibitors [55,57], and auxin-induced $\mathrm{Ca}^{2+}$ changes in leaf wheat protoplasts and root hairs depend strongly on the $\mathrm{Ca}^{2+}$ concentration in the extracellular medium [50,51,58]. Moreover, the direct involvement of plasma membrane-localized channels could be measured in plasma membrane-derived vesicles $[59,60]$. In these experiments, vesicles that consist of $70 \%-80 \%$ of plasma membrane were prepared from maize coleoptiles. Auxin-induced changes in membrane potential were then measured in the context of a different concentration of intraluminal and extraluminal $\mathrm{K}^{+}$and $\mathrm{Ca}^{2+}$. From these measurements, it was inferred that auxin activates cation channels in the plasma membrane that facilitate $\mathrm{Ca}^{2+}$ influx and $\mathrm{K}^{+}$efflux. Consistently, both auxin-induced currents could be inhibited by nifedipine and verapamil $[59,60]$, two $\mathrm{Ca}^{2+}$ channel blockers that were reported to inhibit outward rectifying $\mathrm{K}^{+}$channels [61]. Together, these findings strongly support the involvement of plasma membrane-localized $\mathrm{Ca}^{2+}$ channels to generate auxin-induced $\mathrm{Ca}^{2+}$ signals. Importantly, a large portion of wheat leaf protoplasts showed a LiCl-sensitive, biphasic $\mathrm{Ca}^{2+}$ signal after auxin treatment, suggesting the involvement of intracellular $\mathrm{Ca}^{2+}$ stores [51]. However, it remains to be further explored how intracellular $\mathrm{Ca}^{2+}$ stores contribute to auxin-induced $\mathrm{Ca}^{2+}$ signals. Unfortunately, most of the used dyes and genetically encoded $\mathrm{Ca}^{2+}$ sensors did not yield the needed resolution to detect intracellular sources for auxin-induced $\mathrm{Ca}^{2+}$. Recently, the genetically encoded $\mathrm{Ca}^{2+}$ sensor, aequorin, was targeted to the Golgi apparatus and revealed that application of the synthetic auxin analogue, 2,4-D (2,4-dichlorophenoxyacetic acid), caused a steady/slow decrease of its $\mathrm{Ca}^{2+}$ content, suggestive of a passive $\mathrm{Ca}^{2+}$ loss [62]. To be able to further explore the contributions of the different organelles to auxin-induced $\mathrm{Ca}^{2+}$ fluxes, one would require using a broad range of subcellularly targeted $\mathrm{Ca}^{2+}$ sensors that were recently developed [62-66].

\section{Auxin Receptors for Auxin-Induced $\mathrm{Ca}^{2+}$ Signals}

Several decades of extensive auxin research allowed the mapping of the main auxin signaling pathways. First, and best characterized, are the auxin-induced transcriptional changes that reflect auxin-driven developmental decisions [1]. This pathway is defined by the SCF ${ }^{\text {TIR1/AFB }}$ E3-ligase, Aux/indole-3-acetic acids (Aux/IAAs) and auxin response factors (ARFs) (Figure 1). The Aux/IAAs are repressors of auxin response factors, which recruit the TOPLESS (TPL) co-repressor to these transcription factors. Under high auxin conditions, the interaction between the Transport Inhibitor Response1/Auxin Signaling F-Box (TIR1/AFB) component of the E3-ligase and Aux/IAAs is 
stabilized, resulting in ubiquitination of the Aux/IAA and its subsequent proteasomal degradation. The rapid proteolysis of Aux/IAAs results in the derepression of ARFs and associated transcriptional changes [43]. However, the speed by which auxin can elicit $\mathrm{Ca}^{2+}$ signals precludes the involvement of transcriptional changes, suggesting that it acts independently from the canonical $\mathrm{SCF}^{\mathrm{TIR} 1 / \mathrm{AFB}}$-based auxin signaling cascade. This notion can also be deduced indirectly from the available literature on auxin-induced $\mathrm{pH}$ changes. Within minutes, auxin induces a rapid acidification of the cytosol $[21,54,67,68]$ and an alkalinization of the apoplast in the root cells of Arabidopsis [55]. Interestingly, the auxin-induced apoplast alkalinization of Arabidopsis root cells occurs equally fast in wild-type as in tirl and tirlafb2ab3 mutants [55], suggesting that this process is $\mathrm{SCF}^{\mathrm{TIR} 1 / \mathrm{AFB}}$ independent. On the other hand, both auxin-induced $\mathrm{Ca}^{2+}$ and auxin-induced apoplast alkalinization were abolished in the presence of the general $\mathrm{Ca}^{2+}$ channel inhibitor, $\mathrm{La}^{3+}[55]$. This together suggests a $\mathrm{Ca}^{2+}$-dependence of the apoplast alkalinization response, which is $\mathrm{SCF}^{\mathrm{TIR} 1 / \mathrm{AFB}}$ independent.

An alternative auxin signaling pathway based on the stabilized interaction between F-box protein SKP2A and cell cycle transcription factor DPB was recently proposed to explain the effects of auxin on cell cycle progression [69]. However, as this would also act in the nucleus to drive transcriptional changes, it also seems unlikely that this pathway could account for auxin-induced $\mathrm{Ca}^{2+}$ changes.

A second main auxin receptor is defined by Auxin Binding Protein 1 (ABP1) [3,70-72]. This protein resides mainly in the endoplasmic reticulum (ER), where it is probably unable to bind auxin, due to the high $\mathrm{pH}$. A small fraction of ABP1 seems to escape from the ER via the secretory pathway, to the more acidic apoplast, which is more favorable for auxin binding [73]. In the apoplast, it remains closely associated with the plasma membrane, where it could modulate auxin responses that do not require transcriptional changes, such as membrane hyper/depolarization [74,75], regulation of auxininduced currents of $\mathrm{K}^{+}$and $\mathrm{Cl}^{-}$across the plasma membrane [76,77] and regulation of clathrinmediated endocytosis [39,78-80]. Recently, it was found that ABP1 is required for the auxin-mediated activation of Rho of Plant (ROP) GTPases, which exert their effects through interaction with ROP interactive CRIB (Cdc42/Rac Interactive Binding) motif-containing proteins (RIC) [78] (Figure 1). As ABP1 controls fast auxin responses at the plasma membrane, one might expect that ABP1 also acts upstream of auxin-induced $\mathrm{Ca}^{2+}$ signaling. However, available data are indirect and inconclusive as exemplified in auxin-induced stomatal opening. Firstly, it is well established that auxin induces stomatal opening [81], which has been correlated with the induction of $\mathrm{Ca}^{2+}$ signals and cytosolic acidification in guard cells [21]. Secondly, lowering $\mathrm{Ca}^{2+}$ via ethylene glycol tetraacetic acid (EGTA) prevented auxin-induced stomatal opening [57] indicating that apoplastic $\mathrm{Ca}^{2+}$ is required for auxin-induced stomatal opening. Thirdly, activation of apoplastic ABP1 via exogenous application of a specific antibody induced stomatal opening, while exogenous application of polyclonal antibodies could interfere with auxin-induced stomatal opening [82]. Together, these findings are consistent with a model in which extracellular ABP1 acts upstream of $\mathrm{Ca}^{2+}$ during auxin-induced stomatal opening. However, in mutants defective in AUX1-mediated IAA uptake, IAA could no longer counteract abscisic acid (ABA)-induced stomatal closure [83], arguing against the involvement of an extracellular auxin receptor. Moreover, the $\mathrm{Ca}^{2+}$-dependent portion of auxin-induced protoplast swelling was suggested to be independent of apoplastic ABP1 [84]. 
Figure 1. Scheme of auxin-induced $\mathrm{Ca}^{2+}$ signals. (Left) Canonical $\mathrm{SCF}^{\mathrm{TIR} 1 / \mathrm{AFB}}$-mediated auxin signaling; (Right) ABP1-mediated auxin signaling. The curved arrow represents a hypothetical model in which $\mathrm{Ca}^{2+}$ acts as a connecting signal between ABP1 and $\mathrm{SCF}^{\mathrm{TIR} 1 / \mathrm{AFB}}$ signaling cascades.

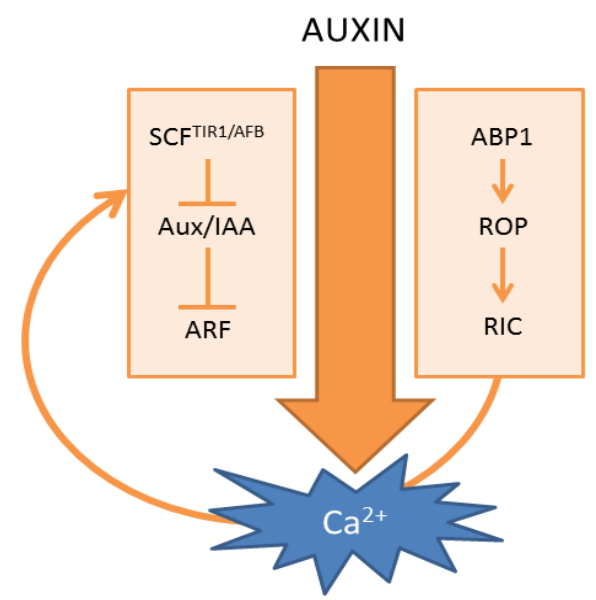

The ABP1 and $\mathrm{SCF}^{\mathrm{TIR} 1 / \mathrm{AFB}}$ signaling cascades are interconnected: in conditional knockdown lines for ABP1, SCF ${ }^{\text {TIR1/AFB }}$-regulated transcripts were less auxin-sensitive [34], and TIR1/AFB-dependent Aux/IAA degradation was enhanced [85]. While the underlying mechanism is currently unknown, one could speculate that $\mathrm{Ca}^{2+}$ acts as a coordinating signal between both signaling cascades (Figure 1). Indeed, the early auxin-responsive gene, TaIAA1, could be controlled by $\mathrm{Ca}^{2+}$ application, which was prevented by $\mathrm{Ca}^{2+}$ chelation [86], suggesting that the $\mathrm{SCF}^{\mathrm{TIR} 1 / \mathrm{AFB}}$ signaling cascade can be controlled by $\mathrm{Ca}^{2+}$ signals, which are potentially generated downstream of ABP1.

\section{Calcium Modulates $\mathrm{pH}$ and Growth}

After the discovery of the molecular nature of auxin, it was readily recognized that auxin can promote or inhibit growth depending on its concentration [87]. At low concentrations, auxin stimulates growth, while high auxin concentrations repress growth.

Auxin-induced growth can be largely explained by a rapid elongation of cells and is correlated with acidification of the apoplast [88], activation of cell wall modifying enzymes [89,90] and $\mathrm{K}^{+}$ uptake [91-93]. These elements have been rationalized in the "Acid Growth Theory" [94-99], which suggests that apoplast acidification is the major regulator of auxin-induced elongation by activating cell wall loosening enzymes and by providing the electrochemical gradient that drives $\mathrm{K}^{+}$uptake, which is necessary for water uptake and cell expansion. This theory provides a nice overview of events that correlate with auxin-induced growth, but remains controversial, due to a lack of strong biochemical and molecular support.

Central to the activation of plasma membrane-localized $\mathrm{H}^{+}$ATPases (AHAs) is the phosphorylation-dependent interaction with a 14-3-3 protein. This interaction, and, thus, proton extrusion, depends mainly on phosphorylation of the penultimate $\mathrm{Thr}$ in its $C$-terminus [100,101], which is also targeted during auxin-induced elongation and occurs with a lag of $\sim 10$ min after auxin application [88]. On the other hand, the interaction between AHA2 and the activating 14-3-3 protein can be inhibited by phosphorylation of a Ser-931 in its $C$-terminus by the protein kinase 
PKS5/CIPK11, which acts in concert with the $\mathrm{Ca}^{2+}$ binding protein, ScaBP1/CBL2 [102], and could explain the $\mathrm{Ca}^{2+}$-dependent root growth inhibition in high auxin levels [103,104]. Importantly, this $\mathrm{Ca}^{2+}$-dependent inhibition could be part of a feedback mechanism that keeps apoplast acidification in check, as arabinogalactan glycoproteins (AGBs) are proposed to act as $\mathrm{pH}$-sensitive $\mathrm{Ca}^{2+}$ sources in the periplasm [105]: Acidification of the apoplast would thus increase the unbound $\mathrm{Ca}^{2+}$ concentration that can contribute to cytosolic $\mathrm{Ca}^{2+}$ signals that inhibit AHA activity (Figure 2).

The existence of two antagonistic pathways for regulating AHA activity with two different auxin sensitivities would provide an easy explanation for the observed concentration-dependent dualism of auxin as a regulator of elongation growth [87] (Figure 2). At suboptimal concentrations, auxin would mainly stimulate AHA activity to drive elongation, until a threshold concentration at which auxin triggers $\mathrm{Ca}^{2+}$-dependent inhibition of AHAs. The auxin receptor for these responses might be ABP1, as auxin-induced elongation and $\mathrm{H}^{+}$ATPase phosphorylations are independent of the canonical SCF ${ }^{\mathrm{TIR} 1 / \mathrm{AFB}}$ signaling pathway $[88,106]$, and antigenic inhibition of ABP1 can prevent auxin-induced $\mathrm{H}^{+}$ATPase activity [72,75,107].

Figure 2. Hypothetical model of auxin concentration-dependent control over apoplastic $\mathrm{pH}$. At low concentrations, auxin activates plasma membrane (PM) $\mathrm{H}^{+}$ATPases, thereby lowering apoplastic $\mathrm{pH}$ and increasing apoplastic $\mathrm{Ca}^{2+}$ concentrations via arabinogalactan glycoproteins (AGBs). At high auxin concentrations, auxin induces a $\mathrm{Ca}^{2+}$ signal that inactivates $\mathrm{H}^{+}$ATPases. The auxin-induced $\mathrm{Ca}^{2+}$ signal can be inhibited by $\mathrm{La}^{3+}$.

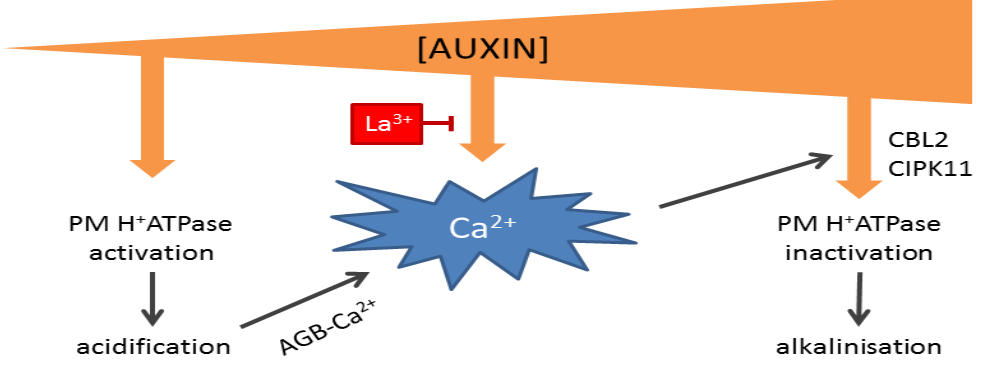

Besides a possible modulation of $\mathrm{H}^{+}$ATPase activity, $\mathrm{Ca}^{2+}$ is well known to control $\mathrm{K}^{+}$uptake via direct regulation of $\mathrm{K}^{+}$channels in guard cells and in roots [108-113]. In these examples, $\mathrm{Ca}^{2+}$ sensing proteins of the calcineurin B-like (CBL) family, together with $\mathrm{CBL}$ interacting kinases (CIPK) or $\mathrm{Ca}^{2+}$-dependent kinases (CPKs), mediate $\mathrm{Ca}^{2+}$-dependent phosphorylation of $\mathrm{K}^{+}$channels to fine-tune their activities. Furthermore, during auxin's effect on osmoregulation, $\mathrm{Ca}^{2+}$ could be an important signal, as high extracellular $\mathrm{Ca}^{2+}$ impairs acid-induced growth, which is associated with reduced inward $\mathrm{K}^{+}$currents [93]. Moreover, $\mathrm{K}^{+}$transporters, TRH1/AtKT3/AtKUP4 [114,115] and ZIFL1 [116], and CIPK6 [117] (which can phosphorylate the $\mathrm{K}^{+}$transporter AKT2 [118]) have been connected to the regulation of auxin transport. Therefore, the effect of $\mathrm{Ca}^{2+}$ on $\mathrm{K}^{+}$channels could be related to regulating osmotic pressure for both cell elongation and for auxin transport.

\section{5. $\mathrm{Ca}^{2+}$ Controls the Rate of Auxin Transport}

As early as the nineteenth century, Charles Darwin already recognized the existence of a mobile signal that moves between the site of light perception and the site of elongation growth during 
phototropic bending [119]. Ever since the discovery of auxin, auxin transport has been recognized as a crucial aspect of auxin-regulated growth [2]. Two types of auxin transport can be distinguished. The first is passive, long-distance auxin transport via the vascular tissues for source-to-sink auxin transport [120]. The second is slower, directional (polar), cell-to-cell transport for auxin-regulated plant development. The latter is one of the main mechanisms by which instructive auxin gradients in tissues are formed to regulate plant development. Interestingly, polar auxin transport was found to be highly dependent on $\mathrm{Ca}^{2+}$ availability [104,121-125]. Together, these findings highlight the importance of $\mathrm{Ca}^{2+}$ in auxin transport.

The minimal mechanistic constituents of polar auxin transport have been delineated in the chemiosmotic polar diffusion hypothesis [126-129] (Figure 3). This model states that the natural auxin, indole-3-acetic acid (IAA), in the acidic environment of the apoplast exist (in part) in its protonated form, which renders it more lipophilic and, thus, allows it to diffuse through the plasma membrane. Once inside the neutral cytosol, it loses its lipophilicity by deprotonation and is trapped inside the cell. The rate of auxin efflux from the cell is, therefore, dependent on the activity of auxin efflux proteins. By extension, this model predicts that asymmetric localization of such auxin efflux transporters could explain polar auxin transport across tissues.

Figure 3. Summary of the effects of $\mathrm{Ca}^{2+}$ on polar auxin transport rates. (a) Cellular $\mathrm{Ca}^{2+}$ signaling impacts on auxin uptake mechanisms via effects on the abundance and activity of the plasma membrane $\mathrm{H}^{+}$ATPase. The amount of protons in the apoplast determine the auxin uptake rate via diffusion of protonated indole-3-acetic acid (IAAH), as well as $\mathrm{H}^{+} / \mathrm{IAA}^{-}$(indole-3-acetic acid) symport; (b) $\mathrm{Ca}^{2+}$ can change the affinity of NRT1.1 for nitrate and auxin uptake; (c) $\mathrm{Ca}^{2+}$ controls the activity of the auxin efflux machinery by modulating the kinase activity of PINOID (PID) and, possibly, also D6PKs. PID also impacts on PIN-formed (PIN) polarity (not depicted). Uptake refers to active uptake mechanisms. Efflux refers to active auxin efflux mechanisms.

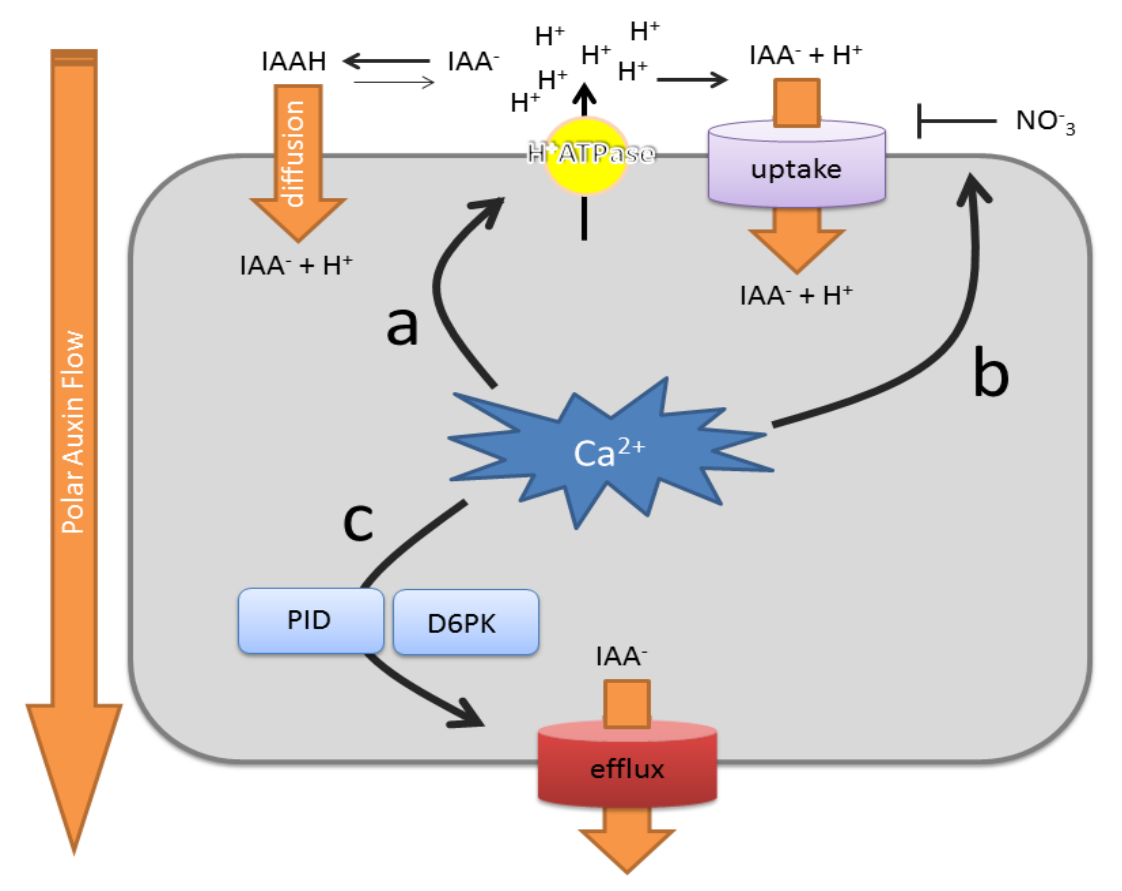


Since the formulation of this model, most of the underlying molecular machinery has been identified and characterized in detail. Besides passive auxin entry, auxin was found to be actively taken up into the cell (Figure 3). This is mainly mediated by auxin influx transporters of the AUX1/LAX family [130,131], at least one member of the ABCB family [132] and the nitrate sensor/transporter, NTR1.1 [133]. The AUX1/LAX proteins are amino acid permease-like proteins that act as high affinity $\mathrm{H}^{+} / \mathrm{IAA}^{-}$symporters [134]. They are involved in efficient auxin uptake into the cell, which is needed for gravitropism [131,135], lateral root emergence [136] and phyllotaxis [137]. Interestingly, vacuolar $\mathrm{Ca}^{2+}$ was found to have a profound, but indirect, impact on AUX1-mediated $\mathrm{H}^{+} / \mathrm{IAA}^{-}$symport, via effects on plasma membrane $\mathrm{H}^{+}$ATPase activity [83] (Figure 3a). Mutants defective in the vacuolar $\mathrm{Ca}^{2+} / \mathrm{H}^{+}$exchangers, CAX1 and CAX3, were insensitive to IAA's inhibitory effect on ABA-induced stomatal closure. This defect in IAA sensitivity could be fully rescued by the lowering of apoplastic $\mathrm{pH}$ in the mutants. This illustrates how vacuolar $\mathrm{Ca}^{2+}$ homeostasis processes can impact on auxin uptake. Similarly, cax 1 mutants show reduced lateral root densities and show IAA-resistant root growth [138], reminiscent of auxl mutant phenotypes [120,139], suggesting that a similar mechanism as described for stomata can explain the observed root phenotypes.

While AUX1/LAX transporters mediate the bulk of the auxin influx into the cell, ABCB4, its close homologue, $\mathrm{ABCB} 21$, and NRT1.1 represent conditional auxin uptake mechanisms. On the one hand, ABCB4 and ABCB21 mediate auxin uptake when auxin levels are low, but catalyze auxin efflux at higher concentrations $[132,140]$. However, no effects of $\mathrm{Ca}^{2+}$ on their auxin transport activity were thus far reported. On the other hand, the NRT1.1/CHL is a dual-affinity nitrate transporter, which also serves as a nitrate sensor [141]. This protein was recently reported to also facilitate auxin uptake [133]. Importantly, NRT1.1-dependent auxin uptake could be inhibited by nitrate, highlighting a direct cross-talk between nutrient sensing and auxin transport. Moreover, NRT1.1's affinity for nitrate is controlled by CIPK23-mediated phosphorylation [141], suggesting that $\mathrm{Ca}^{2+}$ signals control auxin uptake via modulating NRT1.1's affinity for nitrate (Figure 3b).

The other rate-limiting aspect of the polar auxin transport is auxin efflux (Figure 3c). This process is mainly mediated by auxin transporters of the PIN-formed (PIN) family and a subgroup of the ABCB transporter family $[142,143]$. They can transport auxin independently, but also in concert with each other [144-147]. Among the ABCB transporters, ABCB1, ABCB4, ABCB19 and ABCB21 are best characterized for their auxin-transport capacities [140,148,149]. Their auxin efflux activities are stimulated by interaction with the immunophilin-like TWISTED DWARF1 (TWD1) [150,151], and this interaction is inhibited by synthetic and natural auxin transport inhibitors [140,146]. Besides the interaction with TWD1, ABCB1 auxin efflux activity can be impaired or stimulated by phosphorylation via the AGC kinase, PINOID (PID) [146]. In the presence of TWD1, PID-mediated phosphorylation inhibits auxin efflux, whereas it acts in a stimulatory manner in the absence of TWD1. On the other hand, PIN-mediated auxin transport rates can be regulated by D6PK-mediated phosphorylation, another subclade of AGC kinases [152]. Interestingly, PID kinase activity can be enhanced or repressed by interaction with the $\mathrm{Ca}^{2+}$-binding proteins, PID-BINDING PROTEIN 1 (PBP1) and TOUCH 3 (TCH3), respectively [153]. This suggests that $\mathrm{Ca}^{2+}$ can have a positive, as well as a negative, impact on PID activity and, thus, on ABCB-mediated auxin transport. Conversely, as D6PKs are alsoAGC-type kinases, it is tempting to speculate that these kinases could also be regulated by $\mathrm{Ca}^{2+}$-binding proteins to regulate PIN-mediated auxin transport activity. 
These examples demonstrate how $\mathrm{Ca}^{2+}$ could impact on auxin transport rates via direct effects on the auxin transport machinery. However, there are probably even more mechanisms by which $\mathrm{Ca}^{2+}$ can impact on polar auxin transport. One example of this is the recent finding that overexpression of SAUR19, a member of an early auxin responsive protein family that binds with high affinity to calmodulin [154], promotes cell expansion and polar auxin transport by an unknown mechanism [155].

\section{6. $\mathrm{Ca}^{2+}$ in the Balance of Exocytosis and Endocytosis}

While the above examples demonstrate how $\mathrm{Ca}^{2+}$ impacts on the speed of auxin transport, it was already proposed in 1984 that reduced polar auxin transport under low $\mathrm{Ca}^{2+}$ conditions was the result of both a lower velocity and a lower capacity for auxin transport [156]. This implies that $\mathrm{Ca}^{2+}$ controls not only the activity, but also the relative abundance of auxin transporters at the plasma membrane.

Newly biosynthesized PINs are trafficked from the endoplasmic reticulum, via the Golgi apparatus and trans-Golgi Network (TGN) to the plasma membrane. Via clathrin-mediated endocytosis, PIN proteins are removed from the plasma membrane to early endosomes/TGN from which they can be targeted to the vacuole for degradation or recycled for exocytosis at the PM [157]. Thus, the predicted impact of $\mathrm{Ca}^{2+}$ on PIN abundance at the plasma membrane is determined by the balance between exocytosis and endocytosis.

One of the most famous effects of $\mathrm{Ca}^{2+}$ on membrane trafficking in animals is the activation of exocytosis during neurotransmission [158] and hormone secretion [159]. In plants, $\mathrm{Ca}^{2+}$ is also intimately connected to regulated exocytosis, as exemplified in gibberellic acid-induced alpha-amylase secretion [160,161], peroxidase secretion [162,163] and polar growth [164-167]. The stimulatory effect of $\mathrm{Ca}^{2+}$ on exocytosis could also be directly observed by $\mathrm{Ca}^{2+}$-induced increases of membrane capacitance in protoplasts of barley aleurone cells [168,169], maize coleoptiles [170,171], maize root caps [172] and tobacco calli [173]. Additionally, $\mathrm{Ca}^{2+}$ might also increase secretion by stimulating de novo synthesis of secretory cargoes $[173,174]$. That $\mathrm{Ca}^{2+}$ could be involved in PIN secretion would be a plausible assumption; however, without supporting experimental evidence, it remains equally plausible that PINs are constitutively secreted, in a $\mathrm{Ca}^{2+}$-independent manner.

Indications for the involvement of $\mathrm{Ca}^{2+}$ as a coordinator of PIN trafficking derive from the spatial separation of clathrin-mediated endocytosis and exocytosis of polarized PINs [175], which is reminiscent of a polarized tip growth in pollen tubes and root hairs (Figure 4). During tip growth, a tip-focused $\mathrm{Ca}^{2+}$ gradient coordinates secretion, endocytosis and actin dynamics [167,176,177]. Secretory vesicles are polarly delivered to the growing tip via filamentous actin (F-actin), where they cannot fuse to the plasma membrane until the cortical F-actin is depolymerized to allow vesicle docking and fusion [178]. The tip-focused, oscillating $\mathrm{Ca}^{2+}$ induces F-actin depolymerization via activation of ABP29 in lily pollen [179], thereby stimulating exocytosis. During tip growth, too much membrane material is delivered compared to what is necessary for the fast, expansive growth [180]. Therefore, a considerable amount of materials, including regulators, are recycled by endocytosis. In pollen, two types of endocytosis could be distinguished: in the shank and subapical region, clathrin-mediated, actindependent endocytosis occurs, whereas in the apex, bulk endocytosis is actin-independent [181-185]. Thus, the sites of secretion and that of clathrin-mediated endocytosis coincide with high and low $\mathrm{Ca}^{2+}$ 
concentrations, respectively, suggesting that $\mathrm{Ca}^{2+}$ not only stimulates exocytosis, but simultaneously inhibits clathrin-mediated endocytosis.

Figure 4. Scheme of membrane trafficking in tip growth and PIN polarization. (Left) Scheme of a tip-growing cell, with high secretion rates centered on a tip-focused $\mathrm{Ca}^{2+}$ gradient and high endocytosis rates at the shank of the cell; (Right) A cell with polarized PINs at its apical cell side shows high rates of PIN endocytosis at its flanks and polar recycling to the center of its apical domain. Polarized auxin efflux locally causes an increase in auxin concentration, which could elicit $\mathrm{Ca}^{2+}$ signals in the underlying cytoplasm. (endo = clathrin-mediated endocytosis; exo = exocytosis).
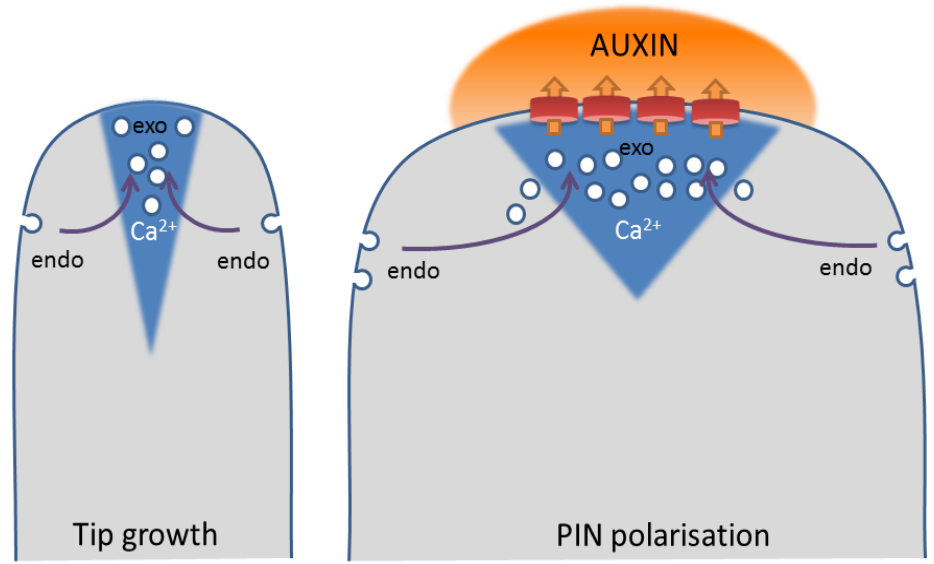

Therefore, auxin-induced $\mathrm{Ca}^{2+}$ could simultaneously induce secretion and inhibit clathrin-mediated endocytosis of PINs, thereby increasing the local auxin transport capacity, resulting locally in higher auxin concentrations, which, in turn, activate $\mathrm{Ca}^{2+}$ signaling. Such a positive feedback mechanism is consistent with our current models of auxin-regulated PIN polarization [175,186]. Thus far, it has been established that auxin can enhance its own efflux by inhibition of clathrin-mediated endocytosis of PINs [38]. Upon perception of auxin, extracellular ABP1 activates Rho of plant (ROP) GTPases to inhibit clathrin-mediated endocytosis via regulation of the actin cytoskeleton [39,78-80]. Recently, $\mathrm{Ca}^{2+}$ was placed upstream of ROP activity in pavement cells, as Rho GDI1 activity depends on phosphorylation by $\mathrm{Ca}^{2+}$-dependent kinase, CPK3 [187]. However, ROP GTPases could also act upstream of $\mathrm{Ca}^{2+}$, as the pollen-specific ROP interactor, RIC3, controls the tip-focused $\mathrm{Ca}^{2+}$ gradient in pollen tubes [188].

Such interplays between $\mathrm{Ca}^{2+}$ and ROPs are potential mechanisms by which signals, such as auxin [37,38], cytokinins [189], strigolactones [190], gibberellins [191,192], salicylic acid [193], etc., could control the turn-over of PINs to change auxin transport.

\section{7. $\mathrm{Ca}^{2+}$ As a Means to Change Auxin Flow Direction}

The plasma membrane-localized PIN proteins show typical asymmetric distribution patterns [2,194] that dictate the auxin flow direction within a given cell [195]. These subcellular polarities are not static, as they can be dynamically rearranged in response to endogenous $[7,9,25,196]$ and exogenous signals [15,36,197,198]. 
Via misexpression studies, it was found that PIN polarities are not only determined by the cell type, but also by cues embedded in the structure of the PIN itself [195]. These polarity-determining signals within the PIN structure can be explained by specific phosphorylations in their hydrophilic loop [199,200] controlled by PINOID [201] and its counteracting phosphatase (PP2A) [202]. Phosphorylation by PINOID impacts on the subcellular trafficking of PINs by modulating their differential recruitment to distinct trafficking routes. In the root, PID-mediated phosphorylation renders PINs insensitive to GNOM-dependent trafficking, resulting in an apical (shootward) polarization [203]. During photostimulation, perception of light represses PID activity, allowing PIN3 to be recruited into GNOM-dependent trafficking toward the inner-lateral side of the cell [16]. Similarly, PID and GNOM activity are involved in PIN3 repolarization during shoot gravitropism [197]. That PID activity can be regulated by interaction with different $\mathrm{Ca}^{2+}$ binding proteins [153] suggests that $\mathrm{Ca}^{2+}$ signals could control PIN polarization via effects on PID activity. Indeed, important $\mathrm{Ca}^{2+}$ signals roughly coincide with PIN polarity changes during phototropism and gravitropism [15,16,197,204-206]. Moreover, mutations or treatments that lead to elevated $\mathrm{Ca}^{2+}$ levels were associated with shifts in PIN polarity [207].

\section{The $\mathrm{Ca}^{2+}$-Auxin Interplay during Gravitropism}

Gravitropism is an excellent example in which the interplay between auxin and $\mathrm{Ca}^{2+}$ is particularly apparent. Gravistimulation induces transient $\mathrm{Ca}^{2+}$ signals in maize coleoptiles [208], whole Arabidopsis seedlings [209], Arabidopsis leaf petioles and hypocotyls [210] and Arabidopsis roots [55]. The auxin dependence of these gravitropism-associated $\mathrm{Ca}^{2+}$ changes was demonstrated by genetic [55] and pharmacological interference with auxin transport [209,210]. Via a highly sensitive, genetically encoded $\mathrm{Ca}^{2+}$ sensor, Yellow Cameleon 3.60, a wave of $\mathrm{Ca}^{2+}$ was visualized that spread across the lower side of the root within minutes after gravistimulus [55], correlating spatially and temporally with the reported dynamics of auxin redistribution [211]. Not only cytosolic $\mathrm{Ca}^{2+}$ showed dynamics that correlate with auxin transport, but also auxin transport-dependent directional movement of $\mathrm{Ca}^{2+}$ across the gravistimulated tissues could be detected [212,213]. The gravistimulus-induced $\mathrm{Ca}^{2+}$ signals are particularly relevant, as gravitropic bending is severely impaired upon chelation of apoplastic $\mathrm{Ca}^{2+}$, inhibition of calmodulin or $\mathrm{Ca}^{2+}$ channels [214-219]. This illustrates the importance for $\mathrm{Ca}^{2+}$ in gravitropic bending. However, the underlying molecular mechanism remains poorly understood and, in some cases, even controversial [13,220].

A potential target of gravistimulus-induced $\mathrm{Ca}^{2+}$ signals is the plant's ability to redirect auxin transport in response to the gravistimulus. Within minutes after graviperception, PIN3 and PIN7 root columella cells repolarize towards the direction of the gravitational pull [15,221], thereby enhancing auxin transport to the new lower side of the root (Figure 5). This additional auxin is efficiently taken up in root cap and epidermal cells via AUX1-mediated $\mathrm{H}^{+} / \mathrm{IAA}^{-}$symport [134,135], to allow rapid efflux towards the root elongation zone via apically localized PIN2 and apical, PID-activated ABCB auxin transporters [146,222,223]. The increased auxin flux via PIN2 is capacitated by transient inhibition of endocytosis, which increases PIN2 abundance at the plasma membrane [37,38]. Simultaneously, the reduced auxin flows across the upper side of the root meristem and destabilizes PIN2 at the plasma membrane [36,37]. These complex effects on auxin transport differentially regulate auxin between the lower and upper side of the root elongation zone, differentially regulating elongation-driven growth 
and, thus, root bending. When Arabidopsis roots reach about the mid-point of bending, the asymmetry in auxin distribution is rapidly lost [211] and is associated with a neutralization of the imbalance of PIN2 abundance by auxin-induced PIN2 degradation [37].

Figure 5. Interplay between auxin transport and calcium signaling during root gravitropism. Graviperception causes PIN repolarization in the columella, redirecting auxin flow to the lower side of the root. The new auxin flux is associated with local $\mathrm{Ca}^{2+}$ signals, altered PIN polarity and turnover, $\mathrm{pH}$ changes and inhibition of elongation. (The black arrow indicates the direction of gravistimulus).

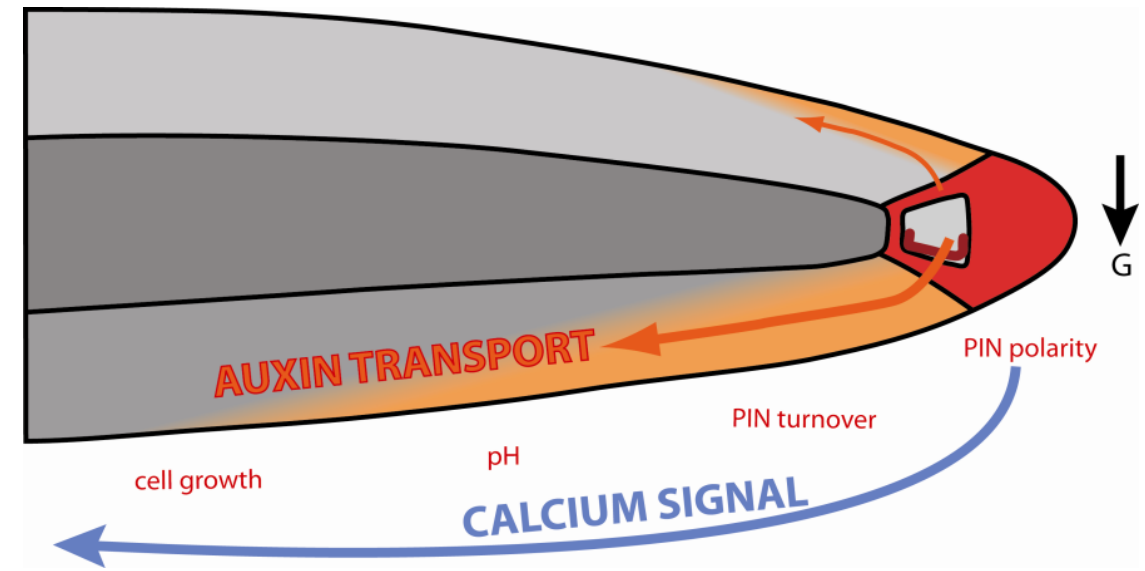

Nearly every step of this summary of auxin-dependent root gravitropism has been highlighted in the paragraphs before as potentially regulated by $\mathrm{Ca}^{2+}$ and can be summarized in the following hypothetical model: Calcium signaling during graviperception activates PIN3 and PIN7 relocation in the columella to redirect auxin flow to the lower side of the gravistimulated root. Here, auxin induces $\mathrm{Ca}^{2+}$ signals that enhance auxin transport by impacting on trafficking, polarity and, even, the activity of the auxin efflux machinery (Figure 5). Moreover, the increase in auxin concentration interferes with elongation growth via inhibition of $\mathrm{H}^{+}$ATPase activity, resulting in differential growth that is associated with root bending.

\section{Conclusions and Future Perspectives}

Following an era of physiological approaches, the auxin field shifted its attention towards elucidating the mechanisms of auxin-regulated transcription. This move has proven to be very successful with the genetic and molecular characterization of $\mathrm{SCF}^{\mathrm{TIR} 1 / \mathrm{AFB}}$-based auxin signal transduction. Numerous aspects of plant development can now be explained via this pathway and are fully justifying the efforts invested. Yet, it is clear that our understanding of auxin signaling will never be complete by only studying auxin-regulated transcription. Recent work on leaf pavement cell morphogenesis and feedback regulation of auxin transport highlighted the non-transcriptional effects of auxin as important aspects of general auxin physiology. Therefore, it will be of interest to revisit some of these physiological experiments in the context of more recent models of auxin action, armed with a new array of cell biological, genetic and molecular tools to gain more holistic insight into the mechanism of auxin-regulated plant growth and development. 


\section{Acknowledgements}

S.V. is a post-doctoral fellow of the Research Foundation-Flanders.

\section{Conflicts of Interest}

The authors declare no conflict of interest.

\section{References}

1. Vanneste, S.; Friml, J. Auxin: A trigger for change in plant development. Cell 2009, 136, 1005-1016.

2. Tanaka, H.; Dhonukshe, P.; Brewer, P.B.; Friml, J. Spatiotemporal asymmetric auxin distribution: A means to coordinate plant development. Cell Mol. Life Sci. 2006, 63, 2738-2754.

3. Napier, R.M.; Venis, M.A. Tansley review No-79-auxin action and auxin-binding proteins. New Phytol. 1995, 129, 167-201.

4. Bennett, T.; Scheres, B. Root development-two meristems for the price of one? Curr. Top. Dev. Biol. 2010, 91, 67-102.

5. Lavenus, J.; Goh, T.; Roberts, I.; Guyomarc'h, S.; Lucas, M.; de Smet, I.; Fukaki, H.; Beeckman, T.; Bennett, M.; Laplaze, L. Lateral root development in Arabidopsis: Fifty shades of auxin. Trends Plant Sci. 2013, 18, 450-458.

6. Reinhardt, D.; Pesce, E.R.; Stieger, P.; Mandel, T.; Baltensperger, K.; Bennett, M.; Traas, J.; Friml, J.; Kuhlemeier, C. Regulation of phyllotaxis by polar auxin transport. Nature 2003, 426, 255-260.

7. Benkova, E.; Michniewicz, M.; Sauer, M.; Teichmann, T.; Seifertova, D.; Jurgens, G.; Friml, J. Local, efflux-dependent auxin gradients as a common module for plant organ formation. Cell 2003, 115, 591-602.

8. Barkoulas, M.; Hay, A.; Kougioumoutzi, E.; Tsiantis, M. A developmental framework for dissected leaf formation in the Arabidopsis relative cardamine hirsuta. Nat. Genet. 2008, 40, $1136-1141$.

9. Scarpella, E.; Marcos, D.; Friml, J.; Berleth, T. Control of leaf vascular patterning by polar auxin transport. Genes Dev. 2006, 20, 1015-1027.

10. Pagnussat, G.C.; Alandete-Saez, M.; Bowman, J.L.; Sundaresan, V. Auxin-dependent patterning and gamete specification in the Arabidopsis female gametophyte. Science 2009, 324, 1684-1689.

11. Zadnikova, P.; Petrasek, J.; Marhavy, P.; Raz, V.; Vandenbussche, F.; Ding, Z.; Schwarzerova, K.; Morita, M.T.; Tasaka, M.; Hejatko, J.; et al. Role of pin-mediated auxin efflux in apical hook development of Arabidopsis thaliana. Development 2010, 137, 607-617.

12. Vandenbussche, F.; Petrasek, J.; Zadnikova, P.; Hoyerova, K.; Pesek, B.; Raz, V.; Swarup, R.; Bennett, M.; Zazimalova, E.; Benkova, E.; et al. The auxin influx carriers AUX1 and LAX3 are involved in auxin-ethylene interactions during apical hook development in Arabidopsis thaliana Seedlings. Development 2010, 137, 597-606.

13. Toyota, M.; Gilroy, S. Gravitropism and mechanical signaling in plants. Am. J. Bot. 2013, 100, $111-125$. 
14. Takahashi, H.; Miyazawa, Y.; Fujii, N. Hormonal interactions during root tropic growth: Hydrotropism versus gravitropism. Plant Mol. Biol. 2009, 69, 489-502.

15. Friml, J.; Wisniewska, J.; Benkova, E.; Mendgen, K.; Palme, K. Lateral relocation of auxin efflux regulator PIN3 mediates tropism in Arabidopsis. Nature 2002, 415, 806-809.

16. Ding, Z.; Galvan-Ampudia, C.S.; Demarsy, E.; Langowski, L.; Kleine-Vehn, J.; Fan, Y.; Morita, M.T.; Tasaka, M.; Fankhauser, C.; Offringa, R.; et al. Light-mediated polarization of the PIN3 auxin transporter for the phototropic response in Arabidopsis. Nat. Cell Biol. 2011, 13, $447-452$.

17. Christie, J.M.; Yang, H.; Richter, G.L.; Sullivan, S.; Thomson, C.E.; Lin, J.; Titapiwatanakun, B.; Ennis, M.; Kaiserli, E.; Lee, O.R.; et al. phot1 inhibition of ABCB19 primes lateral auxin fluxes in the shoot apex required for phototropism. PLoS Biol. 2011, 9, e1001076.

18. Tao, Y.; Ferrer, J.L.; Ljung, K.; Pojer, F.; Hong, F.; Long, J.A.; Li, L.; Moreno, J.E.; Bowman, M.E.; Ivans, L.J.; et al. Rapid synthesis of auxin via a new tryptophan-dependent pathway is required for shade avoidance in plants. Cell 2008, 133, 164-176.

19. Jones, A.R.; Kramer, E.M.; Knox, K.; Swarup, R.; Bennett, M.J.; Lazarus, C.M.; Leyser, H.M.; Grierson, C.S. Auxin transport through non-hair cells sustains root-hair development. Nat. Cell Biol. 2009, 11, 78-84.

20. Ikeda, Y.; Men, S.; Fischer, U.; Stepanova, A.N.; Alonso, J.M.; Ljung, K.; Grebe, M. Local auxin biosynthesis modulates gradient-directed planar polarity in Arabidopsis. Nat. Cell Biol. 2009, 11, 731-738.

21. Irving, H.R.; Gehring, C.A.; Parish, R.W. Changes in cytosolic $\mathrm{pH}$ and calcium of guard cells precede stomatal movements. Proc. Natl. Acad. Sci. USA 1992, 89, 1790-1794.

22. Ding, Z.; Wang, B.; Moreno, I.; Duplakova, N.; Simon, S.; Carraro, N.; Reemmer, J.; Pencik, A.; Chen, X.; Tejos, R.; et al. ER-localized auxin transporter PIN8 regulates auxin homeostasis and male gametophyte development in Arabidopsis. Nat. Commun. 2012, 3, doi:10.1038/ncomms1941.

23. Kim, J.I.; Murphy, A.S.; Baek, D.; Lee, S.W.; Yun, D.J.; Bressan, R.A.; Narasimhan, M.L. Yucca6 over-expression demonstrates auxin function in delaying leaf senescence in Arabidopsis thaliana. J. Exp. Bot. 2011, 62, 3981-3992.

24. Lim, P.O.; Lee, I.C.; Kim, J.; Kim, H.J.; Ryu, J.S.; Woo, H.R.; Nam, H.G. Auxin response Factor 2 (Arf2) plays a major role in regulating auxin-mediated leaf longevity. J. Exp. Bot. 2010, $61,1419-1430$.

25. Sorefan, K.; Girin, T.; Liljegren, S.J.; Ljung, K.; Robles, P.; Galvan-Ampudia, C.S.; Offringa, R.; Friml, J.; Yanofsky, M.F.; Ostergaard, L. A regulated auxin minimum is required for seed dispersal in Arabidopsis. Nature 2009, 459, 583-586.

26. Goetz, M.; Vivian-Smith, A.; Johnson, S.D.; Koltunow, A.M. Auxin response factor 8 is a negative regulator of fruit initiation in Arabidopsis. Plant Cell 2006, 18, 1873-1886.

27. Ellis, C.M.; Nagpal, P.; Young, J.C.; Hagen, G.; Guilfoyle, T.J.; Reed, J.W. Auxin response factor1 and auxin response factor2 regulate senescence and floral organ abscission in Arabidopsis thaliana. Development 2005, 132, 4563-4574.

28. Grunewald, W.; Cannoot, B.; Friml, J.; Gheysen, G. parasitic nematodes modulate PIN-mediated auxin transport to facilitate infection. PLoS Pathog. 2009, 5, e1000266. 
29. Navarro, L.; Dunoyer, P.; Jay, F.; Arnold, B.; Dharmasiri, N.; Estelle, M.; Voinnet, O.; Jones, J.D. A plant miRNA contributes to antibacterial resistance by repressing auxin signaling. Science 2006, 312, 436-439.

30. Iglesias, M.J.; Terrile, M.C.; Bartoli, C.G.; D’ippolito, S.; Casalongue, C.A. Auxin signaling participates in the adaptative response against oxidative stress and salinity by interacting with redox metabolism in Arabidopsis. Plant Mol. Biol. 2010, 74, 215-222.

31. Ding, Z.; Friml, J. Auxin regulates distal stem cell differentiation in Arabidopsis Roots. Proc. Natl. Acad. Sci. USA 2010, 107, 12046-12051.

32. Himanen, K.; Boucheron, E.; Vanneste, S.; de Almeida Engler, J.; Inze, D.; Beeckman, T. Auxin-mediated cell cycle activation during early lateral root initiation. Plant Cell 2002, 14, 2339-2351.

33. Vanneste, S.; de Rybel, B.; Beemster, G.T.; Ljung, K.; de Smet, I.; van Isterdael, G.; Naudts, M.; Iida, R.; Gruissem, W.; Tasaka, M.; et al. Cell cycle progression in the pericycle is not sufficient for solitary root/IAA14-mediated lateral root initiation in Arabidopsis thaliana. Plant Cell 2005, 17, 3035-3050.

34. Tromas, A.; Braun, N.; Muller, P.; Khodus, T.; Paponov, I.A.; Palme, K.; Ljung, K.; Lee, J.Y.; Benfey, P.; Murray, J.A.; et al. The auxin binding protein 1 is required for differential auxin responses mediating root growth. PLoS One 2009, 4, e6648.

35. Xu, T.; Nagawa, S.; Yang, Z. Uniform auxin triggers the rho gtpase-dependent formation of interdigitation patterns in pavement cells. Small Gtpases 2011, 2, 227-232.

36. Abas, L.; Benjamins, R.; Malenica, N.; Paciorek, T.; Wisniewska, J.; Moulinier-Anzola, J.C.; Sieberer, T.; Friml, J.; Luschnig, C. Intracellular Trafficking and proteolysis of the Arabidopsis auxin-efflux facilitator PIN2 are involved in root gravitropism. Nat. Cell Biol. 2006, 8, 249-256.

37. Baster, P.; Robert, S.; Kleine-Vehn, J.; Vanneste, S.; Kania, U.; Grunewald, W.; de Rybel, B.; Beeckman, T.; Friml, J. SCF(TIR1/AFB)-auxin signalling regulates PIN vacuolar trafficking and auxin fluxes during root gravitropism. EMBO J. 2013, 32, 260-274.

38. Paciorek, T.; Zazimalova, E.; Ruthardt, N.; Petrasek, J.; Stierhof, Y.D.; Kleine-Vehn, J.; Morris, D.A.; Emans, N.; Jurgens, G.; Geldner, N.; et al. Auxin Inhibits endocytosis and promotes its own efflux from cells. Nature 2005, 435, 1251-1256.

39. Robert, S.; Kleine-Vehn, J.; Barbez, E.; Sauer, M.; Paciorek, T.; Baster, P.; Vanneste, S.; Zhang, J.; Simon, S.; Covanova, M.; Hayashi, K.; et al. ABP1 mediates auxin inhibition of clathrin-dependent endocytosis in Arabidopsis. Cell 2010, 143, 111-121.

40. Sauer, M.; Robert, S.; Kleine-Vehn, J. Auxin: Simply complicated. J. Exp. Bot. 2013, 64, 2565-2577.

41. Ljung, K. Auxin metabolism and homeostasis during plant development. Development 2013, 140, 943-950.

42. Lokerse, A.S.; Weijers, D. Auxin enters the matrix-Assembly of response machineries for specific outputs. Curr. Opin. Plant Biol. 2009, 12, 520-526.

43. Chapman, E.J.; Estelle, M. Mechanism of auxin-regulated gene expression in plants. Annu. Rev. Genet. 2009, 43, 265-285.

44. Vanstraelen, M.; Benkova, E. Hormonal interactions in the regulation of plant development. Annu. Rev. Cell. Dev. Biol. 2012, 28, 463-487. 
45. Bothwell, J.H.; Ng, C.K. The evolution of $\mathrm{Ca}^{2+}$ signalling in photosynthetic eukaryotes. New Phytol. 2005, 166, 21-38.

46. Verret, F.; Wheeler, G.; Taylor, A.R.; Farnham, G.; Brownlee, C. Calcium channels in photosynthetic eukaryotes: Implications for evolution of calcium-based signalling. New Phytol. 2010, 187, 23-43.

47. Hepler, P.K. Calcium: A central regulator of plant growth and development. Plant Cell 2005, 17, 2142-2155.

48. Kudla, J.; Batistic, O; Hashimoto, K. Calcium signals: The lead currency of plant information processing. Plant Cell 2010, 22, 541-563.

49. Dodd, A.N.; Kudla, J.; Sanders, D. The language of calcium signaling. Annu. Rev. Plant Biol. 2010, 61, 593-620.

50. Shishova, E.; Lindberg, S. Auxin-induced cytosol acidification in wheat leaf protoplasts depends on external concentration of $\mathrm{Ca}^{2+}$. J. Plant Physiol. 1999, 155, 190-196.

51. Shishova, M.; Lindberg, S. Auxin induces an increase of $\mathrm{Ca}^{2+}$ concentration in the cytosol of wheat leaf protoplasts. J. Plant Physiol. 2004, 161, 937-945.

52. Felle, H. Auxin causes oscillations of cytosolic free calcium and $\mathrm{pH}$ in Zea-Mays coleoptiles. Planta 1988, 174, 495-499.

53. Gehring, C.A.; Irving, H.R.; Parish, R.W. Effects of auxin and abscisic-acid on cytosolic calcium and ph in plant-cells. Proc. Natl. Acad. Sci. USA 1990, 87, 9645-9649.

54. Shishova, M.; Yemelyanov, V.; Rudashevskaya, E.; Lindberg, S. A shift in sensitivity to auxin within development of maize seedlings. J. Plant. Physiol. 2007, 164, 1323-1330.

55. Monshausen, G.B.; Miller, N.D.; Murphy, A.S.; Gilroy, S. Dynamics of auxin-dependent $\mathrm{Ca}^{2+}$ and $\mathrm{pH}$ signaling in root growth revealed by integrating high-resolution imaging with automated computer vision-based analysis. Plant J. 2011, 65, 309-318.

56. Wheeler, G.L.; Brownlee, C. $\mathrm{Ca}^{2+}$ signalling in plants and green algae-Changing channels. Trends Plant Sci. 2008, 13, 506-514.

57. Cousson, A.; Vavasseur, A. Putative involvement of cytosolic $\mathrm{Ca}^{2+}$ and gtp-binding proteins in cyclic-GMP-mediated induction of stomatal opening by auxin in Commelina communis L. Planta 1998, 206, 308-314.

58. Ayling, S.M.; Clarkson, D.T. The cytoplasmic streaming response of tomato root hairs to auxin; the role of calcium. Aust. J. Plant Physiol. 1996, 23, 699-708.

59. Shishova, M.F.; Lindberg, S.; Polevoi, V.V. Auxin activation of $\mathrm{Ca}^{2+}$ transport across the plasmalemma of plant cells. Russ. J. Plant Physiol. 1999, 46, 626-633.

60. Shishova, M.F.; Inge-Vechtomova, N.I.; Vykhvalov, K.A.; Rudashevskaya, E.L.; Polevoi, V.V. Auxin-dependent transport of $\mathrm{K}^{+}$and $\mathrm{Ca}^{2+}$ across the membrane of plasmalemma vesicles from coleoptile cells. Russ. J. Plant. Physiol. 1998, 45, 67-73.

61. Thomine, S.; Zimmermann, S.; Vanduijn, B.; Barbier-Brygoo, H.; Guern, J. Calcium-channel antagonists induce direct inhibition of the outward rectifying potassium channel in tobacco protoplasts. FEBS Lett. 1994, 340, 45-50.

62. Ordenes, V.R.; Moreno, I.; Maturana, D.; Norambuena, L.; Trewavas, A.J.; Orellana, A. In vivo analysis of the calcium signature in the plant Golgi apparatus reveals unique dynamics. Cell Calcium 2012, 52, 397-404. 
63. Krebs, M.; Held, K.; Binder, A.; Hashimoto, K.; den Herder, G.; Parniske, M.; Kudla, J.; Schumacher, K. FRET-based genetically encoded sensors allow high-resolution live cell imaging of $\mathrm{Ca}^{2+}$ Dynamics. Plant J. 2012, 69, 181-192.

64. Mehlmer, N.; Parvin, N.; Hurst, C.H.; Knight, M.R.; Teige, M.; Vothknecht, U.C. A toolset of aequorin expression vectors for in planta studies of subcellular calcium concentrations in Arabidopsis thaliana. J. Exp. Bot. 2012, 63, 1751-1761.

65. Costa, A.; Drago, I.; Behera, S.; Zottini, M.; Pizzo, P.; Schroeder, J.I.; Pozzan, T.; lo Schiavo, F. $\mathrm{H} 2 \mathrm{O} 2$ in plant peroxisomes: An in vivo analysis uncovers a $\mathrm{Ca}^{2+}$-dependent scavenging system. Plant J. 2010, 62, 760-772.

66. Logan, D.C.; Knight, M.R. Mitochondrial and cytosolic calcium dynamics are differentially regulated in plants. Plant Physiol. 2003, 133, 21-24.

67. Felle, H.; Brummer, B.; Bertl, A.; Parish, R.W. Indole-3-acetic-acid and fusicoccin cause cytosolic acidification of corn coleoptile cells. Proc. Natl. Acad. Sci. USA 1986, 83, 8992-8995.

68. Brummer, B.; Bertl, A.; Potrykus, I.; Felle, H.; Parish, R.W. Evidence That fusicoccin and indole-3-acetic-acid induce cytosolic acidification of Zea-Mays cells. FEBS Lett. 1985, 189, $109-114$.

69. Jurado, S.; Abraham, Z.; Manzano, C.; Lopez-Torrejon, G.; Pacios, L.F.; Del Pozo, J.C. The Arabidopsis cell cycle f-box protein Skp2a binds to auxin. Plant Cell 2010, 22, 3891-3904.

70. Sauer, M.; Kleine-Vehn, J. Auxin binding protein 1: The outsider. Plant Cell 2011, 23, 2033-2043.

71. Venis, M.A.; Napier, R.M.; Oliver, S. Molecular analysis of auxin-specific signal transduction. Plant Growth Regul. 1996, 18, 1-6.

72. Barbier-Brygoo, H.; Ephritikhine, G.; Klambt, D.; Ghislain, M.; Guern, J. Functional evidence for an auxin receptor at the plasmalemma of tobacco mesophyll protoplasts. Proc. Natl. Acad. Sci. USA 1989, 86, 891-895.

73. Tian, H.; Klambt, D.; Jones, A.M. Auxin-binding protein 1 does not bind auxin within the endoplasmic reticulum despite this being the predominant subcellular location for this hormone receptor. J. Biol. Chem. 1995, 270, 26962-26969.

74. Felle, H.; Peters, W.; Palme, K. The electrical response of maize to auxins. Biochim. Biophys. Acta 1991, 1064, 199-204.

75. Barbier-Brygoo, H.; Ephritikhine, G.; Klambt, D.; Maurel, C.; Palme, K.; Schell, J.; Guern, J. Perception of the auxin signal at the plasma-membrane of tobacco mesophyll protoplasts. Plant $J$. 1991, 1, 83-93.

76. Thiel, G.; Blatt, M.R.; Fricker, M.D.; White, I.R.; Millner, P. Modulation of $\mathrm{K}^{+}$channels in vicia stomatal guard cells by peptide homologs to the auxin-binding protein $C$-terminus. Proc. Natl. Acad. Sci. USA 1993, 90, 11493-11497.

77. Zimmermann, S.; Thomine, S.; Guern, J.; Barbier-Brygoo, H. An anion current at the plasma-membrane of tobacco protoplasts shows ATP-dependent voltage regulation and is modulated by auxin. Plant J. 1994, 6, 707-716.

78. Xu, T.; Wen, M.; Nagawa, S.; Fu, Y.; Chen, J.G.; Wu, M.J.; Perrot-Rechenmann, C.; Friml, J.; Jones, A.M.; Yang, Z. Cell surface- and rho GTPase-based auxin signaling controls cellular interdigitation in Arabidopsis. Cell 2010, 143, 99-110. 
79. Nagawa, S.; Xu, T.; Lin, D.; Dhonukshe, P.; Zhang, X.; Friml, J.; Scheres, B.; Fu, Y.; Yang, Z. Rop GTPase-dependent actin microfilaments promote pin1 polarization by localized inhibition of clathrin-dependent endocytosis. PLoS Biol. 2012, 10, e1001299.

80. Chen, X.; Naramoto, S.; Robert, S.; Tejos, R.; Lofke, C.; Lin, D.; Yang, Z.; Friml, J. ABP1 and ROP6 GTPase signaling regulate clathrin-mediated endocytosis in Arabidopsis roots. Curr. Biol. 2012, 22, 1326-1332.

81. Marten, I.; Lohse, G.; Hedrich, R. Plant-growth hormones control voltage-dependent activity of anion channels in plasma-membrane of guard-cells. Nature 1991, 353, 758-762.

82. Gehring, C.A.; Mcconchie, R.M.; Venis, M.A.; Parish, R.W. Auxin-binding-protein antibodies and peptides influence stomatal opening and alter cytoplasmic pH. Planta 1998, 205, 581-586.

83. Cho, D.; Villiers, F.; Kroniewicz, L.; Lee, S.; Seo, Y.J.; Hirschi, K.D.; Leonhardt, N.; Kwak, J.M. Vacuolar CAX1 and CAX3 influence auxin transport in guard cells via regulation of apoplastic pH. Plant Physiol. 2012, 160, 1293-1302.

84. Yamagami, M.; Haga, K.; Napier, R.M.; Iino, M. Two distinct signaling pathways participate in auxin-induced swelling of pea epidermal protoplasts. Plant Physiol. 2004, 134, 735-747.

85. Tromas, A.; Paque, S.; Stierle, V.; Quettier, A.L.; Muller, P.; Lechner, E.; Genschik, P.; Perrot-Rechenmann, C. Auxin-binding protein 1 is a negative regulator of the SCF (TIR1/AFB) pathway. Nat. Commun. 2013, 4, doi:10.1038/ncomms3496.

86. Singla, B.; Chugh, A.; Khurana, J.P.; Khurana, P. An early auxin-responsive Aux/IAA gene from wheat (Triticum aestivum) is induced by epibrassinolide and differentially regulated by light and calcium. J. Exp. Bot. 2006, 57, 4059-4070.

87. Thimann, K.V. Hormones and the analysis of growth. Plant Physiol. 1938, 13, 437-449.

88. Takahashi, K.; Hayashi, K.; Kinoshita, T. Auxin activates the plasma membrane $\mathrm{H}^{+}$-atpase by phosphorylation during hypocotyl elongation in Arabidopsis. Plant Physiol. 2012, 159, 632-641.

89. Heyn, A.N.J. Molecular-Basis of auxin-regulated extension growth and role of dextranase. Proc. Natl. Acad. Sci. USA 1981, 78, 6608-6612.

90. Heyn, A.N.J. Dextranase activity and auxin-induced cell elongation in coleoptiles of Avena. Biochem. Biophys. Res. Commun. 1970, 38, 831-837.

91. Claussen, M.; Luthen, H.; Blatt, M.; Bottger, M. Auxin-induced growth and its linkage to potassium channels. Planta 1997, 201, 227-234.

92. Philippar, K.; Buchsenschutz, K.; Edwards, D.; Loffler, J.; Luthen, H.; Kranz, E.; Edwards, K.J.; Hedrich, R. The Auxin-induced $\mathrm{K}^{+}$channel gene $\mathrm{Zmk} 1$ in maize functions in coleoptile growth and is required for embryo development. Plant Mol. Biol. 2006, 61, 757-768.

93. Thiel, G.; Brüdern, A.; Gradmann, D. Small inward rectifying $\mathrm{K}^{+}$channels in coleoptiles: Inhibition by external $\mathrm{Ca}^{2+}$ and function in cell elongation. J. Membr. Biol. 1996, 149, 9-20.

94. Rayle, D.L.; Cleland, R.E. Evidence that auxin-induced growth of soybean hypocotyls involves proton excretion. Plant Physiol. 1980, 66, 433-437.

95. Hager, A. Role of the plasma membrane $\mathrm{H}^{+}$-atpase in auxin-induced elongation growth: Historical and new aspects. J. Plant Res. 2003, 116, 483-505.

96. Luthen, H.; Bigdon, M.; Bottger, M. Reexamination of the acid growth theory of auxin action. Plant Physiol. 1990, 93, 931-939. 
97. Hager, A.; Menzel, H.; Krauss, A. Experiments and hypothesis concerning primary action of auxin in elongation growth. Planta 1971, 100, 47-75.

98. Moloney, M.M.; Elliott, M.C.; Cleland, R.E. Acid growth effects in maize roots-Evidence for a link between auxin-economy and proton extrusion in the control of root-growth. Planta 1981, $152,285-291$.

99. Tode, K.; Luthen, H. Fusicoccin- and IAA-induced elongation growth share the same pattern of $\mathrm{K}^{+}$dependence. J. Exp. Bot. 2001, 52, 251-255.

100. Sondergaard, T.E.; Schulz, A.; Palmgren, M.G. Energization of transport processes in plants. roles of the plasma membrane $\mathrm{H}^{+}$-atpase. Plant Physiol. 2004, 136, 2475-2482.

101. Duby, G.; Poreba, W.; Piotrowiak, D.; Bobik, K.; Derua, R.; Waelkens, E.; Boutry, M. Activation of plant plasma membrane $\mathrm{H}^{+}$-ATPase by 14-3-3 proteins is negatively controlled by two phosphorylation sites within the $\mathrm{H}^{+}$-ATPase $C$-terminal region. J. Biol. Chem. 2009, 284, 4213-4221.

102. Fuglsang, A.T.; Guo, Y.; Cuin, T.A.; Qiu, Q.; Song, C.; Kristiansen, K.A.; Bych, K.; Schulz, A.; Shabala, S.; Schumaker, K.S.; et al. Arabidopsis Protein Kinase PKS5 inhibits the plasma membrane $\mathrm{H}^{+}$-atpase by preventing interaction with 14-3-3 Protein. Plant Cell 2007, 19, 1617-1634.

103. Staal, M.; de Cnodder, T.; Simon, D.; Vandenbussche, F.; van der Straeten, D.; Verbelen, J.P.; Elzenga, T.; Vissenberg, K. Apoplastic alkalinization is instrumental for the inhibition of cell elongation in the arabidopsis root by the ethylene precursor 1-aminocyclopropane-1-carboxylic acid. Plant Physiol. 2011, 155, 2049-2055.

104. Hasenstein, K.H.; Evans, M.L. Calcium dependence of rapid auxin action in maize roots. Plant Physiol. 1986, 81, 439-443.

105. Lamport, D.T.; Varnai, P. Periplasmic arabinogalactan glycoproteins act as a calcium capacitor that regulates plant growth and development. New Phytol. 2013, 197, 58-64.

106. Schenck, D.; Christian, M.; Jones, A.; Luthen, H. Rapid auxin-induced cell expansion and gene expression: A four-decade-old question revisited. Plant Physiol. 2010, 152, 1183-1185.

107. Rück, A.; Palme, K.; Venis, M.A.; Napier, R.M.; Felle, R.H. Patch-clamp analysis establishes a role for an auxin-binding protein in the auxin stimulation of plasma-membrane current in Zea-mays protoplasts. Plant $J$. 1993, 4, 41-46.

108. Ivashikina, N.; Deeken, R.; Fischer, S.; Ache, P.; Hedrich, R. AKT2/3 subunits render guard cell $\mathrm{K}^{+}$Channels $\mathrm{Ca}^{2+}$ sensitive. J. Gen. Physiol. 2005, 125, 483-492.

109. Cheong, Y.H.; Pandey, G.K.; Grant, J.J.; Batistic, O.; Li, L.; Kim, B.G.; Lee, S.C.; Kudla, J.; Luan, S. Two calcineurin b-like calcium sensors, interacting with protein kinase CIPK23, regulate leaf transpiration and root potassium uptake in Arabidopsis. Plant J. 2007, 52, 223-239.

110. Lan, W.Z.; Lee, S.C.; Che, Y.F.; Jiang, Y.Q.; Luan, S. Mechanistic analysis of AKT1 regulation by the CBL-CIPK-PP2CA interactions. Mol. Plant 2011, 4, 527-536.

111. Ren, X.L.; Qi, G.N.; Feng, H.Q.; Zhao, S.; Zhao, S.S.; Wang, Y.; Wu, W.H. Calcineurin B-like protein CBL10 directly interacts with AKT1 and modulates $\mathrm{K}^{+}$homeostasis in Arabidopsis. Plant J. 2013, 74, 258-266.

112. Li, L.; Kim, B.G.; Cheong, Y.H.; Pandey, G.K.; Luan, S. A $\mathrm{Ca}^{2+}$ signaling pathway regulates a $\mathrm{K}^{+}$ channel for low-K response in Arabidopsis. Proc. Natl. Acad. Sci. USA 2006, 103, 12625-12630. 
113. Li, J.; Lee, Y.R.; Assmann, S.M. Guard cells possess a calcium-dependent protein kinase that phosphorylates the KAT1 potassium channel. Plant Physiol. 1998, 116, 785-795.

114. Vicente-Agullo, F.; Rigas, S.; Desbrosses, G.; Dolan, L.; Hatzopoulos, P.; Grabov, A. Potassium carrier TRH1 is required for auxin transport in Arabidopsis roots. Plant J. 2004, 40, 523-535.

115. Rigas, S.; Ditengou, F.A.; Ljung, K.; Daras, G.; Tietz, O.; Palme, K.; Hatzopoulos, P. Root gravitropism and root hair development constitute coupled developmental responses regulated by auxin homeostasis in the arabidopsis root apex. New Phytol. 2013, 197, 1130-1141.

116. Remy, E.; Cabrito, T.R.; Baster, P.; Batista, R.A.; Teixeira, M.C.; Friml, J.; Sa-Correia, I.; Duque, P. A major facilitator superfamily transporter plays a dual role in polar auxin transport and drought stress tolerance in Arabidopsis. Plant Cell 2013, 25, 901-926.

117. Tripathi, V.; Parasuraman, B.; Laxmi, A.; Chattopadhyay, D. CIPK6, A CBL-interacting protein kinase is required for development and salt tolerance in plants. Plant J. 2009, 58, 778-790.

118. Held, K.; Pascaud, F.; Eckert, C.; Gajdanowicz, P.; Hashimoto, K.; Corratge-Faillie, C.; Offenborn, J.N.; Lacombe, B.; Dreyer, I.; Thibaud, J.B.; et al. Calcium-dependent modulation and plasma membrane targeting of the AKT2 potassium channel by the CBL4/CIPK6 calcium sensor/protein kinase complex. Cell Res. 2011, 21, 1116-1130.

119. Darwin, C.; Darwin, F. The Power of Movement in Plants. Appleton and Co.: New York, NY, USA, 1881.

120. Marchant, A.; Bhalerao, R.; Casimiro, I.; Eklof, J.; Casero, P.J.; Bennett, M.; Sandberg, G. AUX1 promotes lateral root formation by facilitating indole-3-acetic acid distribution between sink and source tissues in the Arabidopsis Seedling. Plant Cell 2002, 14, 589-597.

121. Tang, P.M.; Dela Fuente, R.K. The Transport of indole-3-acetic acid in boron- and calcium-deficient sunflower hypocotyl segments. Plant Physiol. 1986, 81, 646-650.

122. Tang, P.M.; Dela Fuente, R.K. Boron and calcium sites involved in indole-3-acetic acid transport in sunflower hypocotyl segments. Plant Physiol. 1986, 81, 651-655.

123. Dela Fuente, R.K.; Leopold, A.C. Role for calcium in auxin transport. Plant Physiol. 1973, 51, 845-847.

124. Evans, M.L.; Young, L.M.; Hasenstein, K.H. The role of calcium in the regulation of hormone transport in gravistimulated Roots. Adv. Space Res. 1992, 12, 211-218.

125. Migliaccio, F.; Galston, A.W. On the role of calcium in indole-3-acetic acid movement and graviresponse in etiolated pea epicotyls. Plant Growth Regul. 1989, 8, 335-347.

126. Raven, J.A. Transport of indole-acetic-acid in plant cells in relation to $\mathrm{pH}$ and electrical potential gradients, and its significance for polar IAA Transport. New Phytol. 1975, 74, 163-172.

127. Rubery, P.H.; Sheldrake, A.R. Carrier-mediated auxin transport. Planta 1974, 118, 101-121.

128. rubery, P.H.; sheldrake, A.R. Effect of $\mathrm{pH}$ and surface charge on cell uptake of auxin. Nature 1973, 244, 285-288.

129. Goldsmith, M.H.; Goldsmith, T.H.; Martin, M.H. Mathematical analysis of the chemosmotic polar diffusion of auxin through plant tissues. Proc. Natl. Acad. Sci. USA 1981, 78, 976-980.

130. Peret, B.; Swarup, K.; Ferguson, A.; Seth, M.; Yang, Y.; Dhondt, S.; James, N.; Casimiro, I.; Perry, P.; Syed, A.; et al. AUX/LAX genes encode a family of auxin influx transporters that perform distinct functions during arabidopsis development. Plant Cell 2012, 24, 2874-2885. 
131. Bennett, M.J.; Marchant, A.; Green, H.G.; May, S.T.; Ward, S.P.; Millner, P.A.; Walker, A.R.; Schulz, B.; Feldmann, K.A. Arabidopsis AUX1 gene: A permease-like regulator of root gravitropism. Science 1996, 273, 948-950.

132. Kubes, M.; Yang, H.; Richter, G.L.; Cheng, Y.; Mlodzinska, E.; Wang, X.; Blakeslee, J.J.; Carraro, N.; Petrasek, J.; Zazimalova, E.; et al. The Arabidopsis concentration-dependent influx/efflux transporter abcb4 regulates cellular auxin levels in the root epidermis. Plant J. 2012, 69, 640-654.

133. Krouk, G.; Lacombe, B.; Bielach, A.; Perrine-Walker, F.; Malinska, K.; Mounier, E.; Hoyerova, K.; Tillard, P.; Leon, S.; Ljung, K.; et al. Nitrate-regulated auxin transport by Nrt1.1 defines a mechanism for nutrient sensing in plants. Dev. Cell 2010, 18, 927-937.

134. Yang, Y.; Hammes, U.Z.; Taylor, C.G.; Schachtman, D.P.; Nielsen, E. High-affinity auxin transport by the AUX1 influx carrier protein. Curr. Biol. 2006, 16, 1123-1127.

135. Swarup, R.; Kramer, E.M.; Perry, P.; Knox, K.; Leyser, H.M.; Haseloff, J.; Beemster, G.T.; Bhalerao, R.; Bennett, M.J. Root gravitropism requires lateral root cap and epidermal cells for transport and response to a mobile auxin signal. Nat. Cell Biol. 2005, 7, 1057-1065.

136. Swarup, K.; Benkova, E.; Swarup, R.; Casimiro, I.; Peret, B.; Yang, Y.; Parry, G.; Nielsen, E.; de Smet, I.; Vanneste, S.; et al. The auxin influx carrier Lax3 promotes lateral root emergence. Nat. Cell Biol. 2008, 10, 946-954.

137. Bainbridge, K.; Guyomarc'h, S.; Bayer, E.; Swarup, R.; Bennett, M.; Mandel, T.; Kuhlemeier, C. Auxin influx carriers stabilize phyllotactic patterning. Genes Dev. 2008, 22, 810-823.

138. Cheng, N.H.; Pittman, J.K.; Barkla, B.J.; Shigaki, T.; Hirschi, K.D. The Arabidopsis Cax1 mutant exhibits impaired ion homeostasis, development, and hormonal responses and reveals interplay among vacuolar transporters. Plant Cell 2003, 15, 347-364.

139. Pickett, F.B.; Wilson, A.K.; Estelle, M. The Aux 1 mutation of Arabidopsis confers both auxin and ethylene resistance. Plant Physiol. 1990, 94, 1462-1466.

140. Kamimoto, Y.; Terasaka, K.; Hamamoto, M.; Takanashi, K.; Fukuda, S.; Shitan, N.; Sugiyama, A.; Suzuki, H.; Shibata, D.; Wang, B.; et al. Arabidopsis ABCB21 is a facultative auxin importer/exporter regulated by cytoplasmic auxin concentration. Plant Cell Physiol. 2012, 53, 2090-2100.

141. Ho, C.H.; Lin, S.H.; Hu, H.C.; Tsay, Y.F. CHL1 functions as a nitrate sensor in plants. Cell 2009, 138, 1184-1194.

142. Petrasek, J.; Mravec, J.; Bouchard, R.; Blakeslee, J.J.; Abas, M.; Seifertova, D.; Wisniewska, J.; Tadele, Z.; Kubes, M.; Covanova, M.; et al. PIN proteins perform a rate-limiting function in cellular auxin efflux. Science 2006, 312, 914-918.

143. Yang, H.; Murphy, A.S. Functional expression and characterization of Arabidopsis ABCB, AUX 1 and PIN auxin transporters in Schizosaccharomyces pombe. Plant J. 2009, 59, 179-191.

144. Blakeslee, J.J.; Bandyopadhyay, A.; Lee, O.R.; Mravec, J.; Titapiwatanakun, B.; Sauer, M.; Makam, S.N.; Cheng, Y.; Bouchard, R.; Adamec, J.; et al. Interactions among PIN-formed and Pglycoprotein auxin transporters in Arabidopsis. Plant Cell 2007, 19, 131-147.

145. Mravec, J.; Kubes, M.; Bielach, A.; Gaykova, V.; Petrasek, J.; Skupa, P.; Chand, S.; Benkova, E.; Zazimalova, E.; Friml, J. Interaction of PIN and PGP transport mechanisms in auxin distributiondependent development. Development 2008, 135, 3345-3354. 
146. Henrichs, S.; Wang, B.; Fukao, Y.; Zhu, J.; Charrier, L.; Bailly, A.; Oehring, S.C.; Linnert, M.; Weiwad, M.; Endler, A.; et al. Regulation of ABCB1/PGP1-catalysed auxin transport by linker phosphorylation. EMBO J. 2012, 31, 2965-2980.

147. Titapiwatanakun, B.; Murphy, A.S. Post-transcriptional regulation of auxin transport proteins: Cellular trafficking, protein phosphorylation, protein maturation, ubiquitination, and membrane composition. J. Exp. Bot. 2009, 60, 1093-1107.

148. Cho, M.; Lee, S.H.; Cho, H.T. P-glycoprotein4 displays auxin efflux transporter-like action in Arabidopsis root hair cells and tobacco cells. Plant Cell 2007, 19, 3930-3943.

149. Geisler, M.; Blakeslee, J.J.; Bouchard, R.; Lee, O.R.; Vincenzetti, V.; Bandyopadhyay, A.; Titapiwatanakun, B.; Peer, W.A.; Bailly, A.; Richards, E.L.; et al. Cellular efflux of auxin catalyzed by the arabidopsis MDR/PGP transporter AtPGP1. Plant J. 2005, 44, 179-194.

150. Bouchard, R.; Bailly, A.; Blakeslee, J.J.; Oehring, S.C.; Vincenzetti, V.; Lee, O.R.; Paponov, I.; Palme, K.; Mancuso, S.; Murphy, A.S.; et al. Immunophilin-like twisted DWARF1 modulates auxin efflux activities of Arabidopsis P-glycoproteins. J. Biol. Chem. 2006, 281, 30603-30612.

151. Wang, B.; Bailly, A.; Zwiewka, M.; Henrichs, S.; Azzarello, E.; Mancuso, S.; Maeshima, M.; Friml, J.; Schulz, A.; Geisler, M. Arabidopsis TWISTED DWARF1 functionally interacts with auxin exporter ABCB1 on the root plasma membrane. Plant Cell 2013, 25, 202-214.

152. Willige, B.C.; Ahlers, S.; Zourelidou, M.; Barbosa, I.C.; Demarsy, E.; Trevisan, M.; Davis, P.A.; Roelfsema, M.R.; Hangarter, R.; Fankhauser, C.; et al. D6PK AGCVIII kinases are required for auxin transport and phototropic hypocotyl bending in Arabidopsis. Plant Cell 2013, 25, 1674-1688.

153. Benjamins, R.; Ampudia, C.S.; Hooykaas, P.J.; Offringa, R. Pinoid-mediated signaling involves calcium-binding proteins. Plant Physiol. 2003, 132, 1623-1630.

154. Yang, T.; Poovaiah, B.W. Molecular and biochemical evidence for the involvement of calcium/calmodulin in auxin action. J. Biol. Chem. 2000, 275, 3137-3143.

155. Spartz, A.K.; Lee, S.H.; Wenger, J.P.; Gonzalez, N.; Itoh, H.; Inze, D.; Peer, W.A.; Murphy, A.S.; Overvoorde, P.J.; Gray, W.M. The SAUR19 subfamily of small auxin up RNA genes promote cell expansion. Plant J. 2012, 70, 978-990.

156. Dela Fuente, R.K. Role Of calcium in the polar secretion of indoleacetic acid. Plant Physiol. 1984, 76, 342-346.

157. Grunewald, W.; Friml, J. The march of the pins: Developmental plasticity by dynamic polar targeting in plant cells. EMBO J. 2010, 29, 2700-2714.

158. Cousin, M.A. Synaptic vesicle endocytosis: Calcium works overtime in the nerve terminal. Mol. Neurobiol. 2000, 22, 115-128.

159. Dolensek, J.; Skelin, M.; Rupnik, M.S. Calcium dependencies of regulated exocytosis in different endocrine cells. Physiol. Res. 2011, 60, S29-S38.

160. Chrispeels, M.J.; Varner, J.E. Gibberellic acid-enhanced synthesis and release of alpha-amylase and ribonuclease by isolated barley and aleurone layers. Plant Physiol. 1967, 42, 398-406.

161. Bush, D.S.; Cornejo, M.J.; Huang, C.N.; Jones, R.L. Ca-stimulated secretion of alpha-amylase during development in barley aleurone protoplasts. Plant Physiol. 1986, 82, 566-574.

162. Sticher, L.; Penel, C.; Greppin, H. Calcium requirement for the secretion of peroxidases by plant cell suspensions. J. Cell Sci. 1981, 48, 345-353. 
163. Castillo, F.J.; Penel, C.; Greppin, H. Peroxidase release induced by ozone in sedum album leaves: Involvement of Ca. Plant Physiol. 1984, 74, 846-851.

164. Campanoni, P.; Blatt, M.R. Membrane trafficking and polar growth in root hairs and pollen tubes. J. Exp. Bot. 2007, 58, 65-74.

165. Coelho, S.M.B.; Brownlee, C.; Bothwell, J.H.F. A Tip-high, $\mathrm{Ca}^{2+}$-interdependent, reactive oxygen species gradient is associated with polarized growth in fucus serratus zygotes. Planta 2008, 227, 1037-1046.

166. Kroeger, J.; Geitmann, A. The pollen tube paradigm revisited. Curr. Opin. Plant Biol. 2012, 15, 618-624.

167. Samaj, J.; Muller, J.; Beck, M.; Bohm, N.; Menzel, D. Vesicular trafficking, cytoskeleton and signalling in root hairs and pollen tubes. Trends Plant Sci. 2006, 11, 594-600.

168. Homann, U.; Tester, M. $\mathrm{Ca}^{2+}$-independent and $\mathrm{Ca}^{2+} / \mathrm{GTP}$-binding protein-controlled exocytosis in a plant cell. Proc. Natl. Acad. Sci. USA 1997, 94, 6565-6570.

169. Tester, M.; Zorec, R. Cytoplasmic calcium stimulates exocytosis in a plant secretory cell. Biophys. J. 1992, 63, 864-867.

170. Sutter, J.U.; Homann, U.; Thiel, G. $\mathrm{Ca}^{2+}$-stimulated exocytosis in maize coleoptile cells. Plant Cell 2000, 12, 1127-1136.

171. Thiel, G.; Sutter, J.U.; Homann, U. $\mathrm{Ca}^{2+}$-sensitive and $\mathrm{Ca}^{2+}$-Insensitive exocytosis in maize coleoptile protoplasts. Pflugers Arch. 2000, 439, R152-R153.

172. Carroll, A.D.; Moyen, C.; van Kesteren, P.; Tooke, F.; Battey, N.H.; Brownlee, C. Ca ${ }^{2+}$, annexins, and gtp modulate exocytosis from maize root cap protoplasts. Plant Cell 1998, 10, $1267-1276$.

173. Sutter, J.U.; Denecke, J.; Thiel, G. Synthesis of vesicle cargo determines amplitude of $\mathrm{Ca}^{2+}$-sensitive exocytosis. Cell Calcium 2012, 52, 283-288.

174. Jones, R.L.; Carbonell, J. Regulation of the synthesis of barley aleurone alpha-amylase by gibberellic acid and calcium Ions. Plant Physiol. 1984, 76, 213-218.

175. Kleine-Vehn, J.; Wabnik, K.; Martiniere, A.; Langowski, L.; Willig, K.; Naramoto, S.; Leitner, J.; Tanaka, H.; Jakobs, S.; Robert, S.; et al. Recycling, clustering, and endocytosis jointly maintain PIN auxin carrier polarity at the plasma membrane. Mol. Syst. Biol. 2011, 7, doi:10.1038/msb.2011.72.

176. Camacho, L.; Malho, R. Endo/exocytosis in the pollen tube apex is differentially regulated by $\mathrm{Ca}^{2+}$ and GTPases. J. Exp. Bot. 2003, 54, 83-92.

177. Cole, R.A.; Fowler, J.E. Polarized growth: Maintaining focus on the tip. Curr. Opin. Plant Biol. 2006, 9, 579-588.

178. Lee, Y.J.; Szumlanski, A.; Nielsen, E.; Yang, Z. Rho-GTPase-dependent filamentous actin dynamics coordinate vesicle targeting and exocytosis during tip growth. J. Cell Biol. 2008, 181, 1155-1168.

179. Xiang, Y.; Huang, X.; Wang, T.; Zhang, Y.; Liu, Q.; Hussey, P.J.; Ren, H. Actin binding protein 29 from lilium pollen plays an important role in dynamic actin remodeling. Plant Cell 2007, 19, 1930-1946.

180. Ketelaar, T.; Galway, M.E.; Mulder, B.M.; Emons, A.M. Rates of exocytosis and endocytosis in arabidopsis root hairs and pollen tubes. J. Microsc. 2008, 231, 265-273. 
181. Derksen, J.; Rutten, T.; Lichtscheidl, I.K.; Dewin, A.H.N.; Pierson, E.S.; Rongen, G. Quantitative-analysis of the distribution of organelles in tobacco pollen tubes-Implications for exocytosis and endocytosis. Protoplasma 1995, 188, 267-276.

182. Lisboa, S.; Scherer, G.E.; Quader, H. Localized endocytosis in tobacco pollen tubes: Visualisation and dynamics of membrane retrieval by a fluorescent phospholipid. Plant Cell Rep. 2008, 27, 21-28.

183. Moscatelli, A.; Ciampolini, F.; Rodighiero, S.; Onelli, E.; Cresti, M.; Santo, N.; Idilli, A. Distinct endocytic pathways identified in tobacco pollen tubes using charged nanogold. J. Cell Sci. 2007, 120, 3804-3819.

184. Moscatelli, A.; Idilli, A.I.; Rodighiero, S.; Caccianiga, M. Inhibition of actin polymerisation by low concentration latrunculin B affects endocytosis and alters exocytosis in shank and tip of tobacco pollen tubes. Plant Biol. 2012, 14, 770-782.

185. Zonia, L.; Munnik, T. Vesicle trafficking dynamics and visualization of zones of exocytosis and endocytosis in tobacco pollen tubes. J. Exp. Bot. 2008, 59, 861-873.

186. Wabnik, K.; Govaerts, W.; Friml, J.; Kleine-Vehn, J. Feedback models for polarized auxin transport: An emerging trend. Mol. Biosyst. 2011, 7, 2352-2359.

187. Wu, Y.; Zhao, S.; Tian, H.; He, Y.; Xiong, W.; Guo, L. CPK3-phosphorylated RhoGDI1 is essential in the development of Arabidopsis seedlings and leaf epidermal cells. J. Exp. Bot. 2013, 64, 3327-3338.

188. Lee, Y.J.; Yang, Z. Tip growth: Signaling in the apical dome. Curr. Opin. Plant Biol. 2008, 11, $662-671$.

189. Marhavy, P.; Bielach, A.; Abas, L.; Abuzeineh, A.; Duclercq, J.; Tanaka, H.; Parezova, M.; Petrasek, J.; Friml, J.; Kleine-Vehn, J.; et al. Cytokinin modulates endocytic trafficking of PIN1 auxin efflux carrier to control plant organogenesis. Dev. Cell 2011, 21, 796-804.

190. Shinohara, N.; Taylor, C.; Leyser, O. Strigolactone can promote or inhibit shoot branching by triggering rapid depletion of the auxin efflux protein PIN1 from the plasma membrane. PLoS Biol. 2013, 11, e1001474.

191. Löfke, C.; Zwiewka, M.; Heilmann, I.; van Montagu, M.C.; Teichmann, T.; Friml, J. Asymmetric gibberellin signaling regulates vacuolar trafficking of PIN auxin transporters during root gravitropism. Proc. Natl. Acad. Sci. USA 2013, 110, 3627-3632.

192. Willige, B.C.; Isono, E.; Richter, R.; Zourelidou, M.; Schwechheimer, C. Gibberellin regulates PIN-formed abundance and is required for auxin transport-dependent growth and development in Arabidopsis thaliana. Plant Cell 2011, 23, 2184-2195.

193. Du, Y.; Tejos, R.; Beck, M.; Himschoot, E.; Li, H.; Robatzek, S.; Vanneste, S.; Friml, J. Salicylic acid interferes with clathrin-mediated endocytic protein trafficking. Proc. Natl. Acad. Sci. USA 2013, 110, 7946-7951.

194. Feraru, E.; Friml, J. PIN polar targeting. Plant Physiol. 2008, 147, 1553-1559.

195. Wisniewska, J.; Xu, J.; Seifertova, D.; Brewer, P.B.; Ruzicka, K.; Blilou, I.; Rouquie, D.; Benkova, E.; Scheres, B.; Friml, J. Polar PIN localization directs auxin flow in plants. Science 2006, 312, doi: 10.1126/science.1121356. 
196. Friml, J.; Vieten, A.; Sauer, M.; Weijers, D.; Schwarz, H.; Hamann, T.; Offringa, R.; Jurgens, G. Efflux-dependent auxin gradients establish the apical-basal axis of Arabidopsis. Nature 2003, 426, 147-153.

197. Rakusova, H.; Gallego-Bartolome, J.; Vanstraelen, M.; Robert, H.S.; Alabadi, D.; Blazquez, M.A.; Benkova, E.; Friml, J. Polarization of PIN3-dependent auxin transport for hypocotyl gravitropic response in Arabidopsis thaliana. Plant J. 2011, 67, 817-826.

198. Sauer, M.; Balla, J.; Luschnig, C.; Wisniewska, J.; Reinohl, V.; Friml, J.; Benkova, E. Canalization of auxin flow by AUX/IAA-ARF-dependent feedback regulation of PIN polarity. Genes Dev. 2006, 20, 2902-2911.

199. Huang, F.; Zago, M.K.; Abas, L.; van Marion, A.; Galvan-Ampudia, C.S.; Offringa, R. Phosphorylation of conserved PIN motifs directs arabidopsis pin1 polarity and auxin transport. Plant Cell 2010, 22, 1129-1142.

200. Zhang, J.; Nodzynski, T.; Pencik, A.; Rolcik, J.; Friml, J. PIN Phosphorylation is sufficient to mediate pin polarity and direct auxin transport. Proc. Natl. Acad. Sci. USA 2010, 107, 918-922.

201. Friml, J.; Yang, X.; Michniewicz, M.; Weijers, D.; Quint, A.; Tietz, O.; Benjamins, R.; Ouwerkerk, P.B.; Ljung, K.; Sandberg, G.; et al. A pinoid-dependent binary switch in apical-basal PIN polar targeting directs auxin efflux. Science 2004, 306, 862-865.

202. Michniewicz, M.; Zago, M.K.; Abas, L.; Weijers, D.; Schweighofer, A.; Meskiene, I.; Heisler, M.G.; Ohno, C.; Zhang, J.; Huang, F.; et al. Antagonistic regulation of pin phosphorylation by PP2A and PINOID directs auxin flux. Cell 2007, 130, 1044-1056.

203. Kleine-Vehn, J.; Huang, F.; Naramoto, S.; Zhang, J.; Michniewicz, M.; Offringa, R.; Friml, J. PIN auxin efflux carrier polarity is regulated by pinoid kinase-mediated recruitment into GNOMindependent trafficking in Arabidopsis. Plant Cell 2009, 21, 3839-3849.

204. Babourina, O.; Newman, I.; Shabala, S. Blue light-induced kinetics of $\mathrm{H}^{+}$and $\mathrm{Ca}^{2+}$ fluxes in etiolated wild-type and phototropin-mutant arabidopsis seedlings. Proc. Natl. Acad. Sci. USA 2002, 99, 2433-2438.

205. Chen, X.; Lin, W.H.; Wang, Y.; Luan, S.; Xue, H.W. An inositol polyphosphate 5-phosphatase functions in phototropin1 signaling in Arabidopis by altering cytosolic $\mathrm{Ca}^{2+}$. Plant Cell 2008, 20 , 353-366.

206. Perera, I.Y.; Hung, C.Y.; Brady, S.; Muday, G.K.; Boss, W.F. A universal role for inositol 1,4,5-trisphosphate-mediated signaling in plant gravitropism. Plant Physiol. 2006, 140, 746-760.

207. Zhang, J.; Vanneste, S.; Brewer, P.B.; Michniewicz, M.; Grones, P.; Kleine-Vehn, J.; Lofke, C.; Teichmann, T.; Bielach, A.; Cannoot, B.; et al. Inositol trisphosphate-induced $\mathrm{Ca}^{2+}$ signaling modulates auxin transport and PIN polarity. Dev. Cell 2011, 20, 855-866.

208. Gehring, C.A.; Williams, D.A.; Cody, S.H.; Parish, R.W. Phototropism and geotropism in maize coleoptiles are spatially correlated with increases in cytosolic free calcium. Nature 1990, 345, 528-530.

209. Plieth, C.; Trewavas, A.J. Reorientation of seedlings in the earth's gravitational field induces cytosolic calcium transients. Plant Physiol. 2002, 129, 786-796.

210. Toyota, M.; Furuichi, T.; Tatsumi, H.; Sokabe, M. Cytoplasmic calcium increases in response to changes in the gravity vector in hypocotyls and petioles of Arabidopsis seedlings. Plant Physiol. 2008, 146, 505-514. 
211. Band, L.R.; Wells, D.M.; Larrieu, A.; Sun, J.; Middleton, A.M.; French, A.P.; Brunoud, G.; Sato, E.M.; Wilson, M.H.; Peret, B.; et al. Root gravitropism is regulated by a transient lateral auxin gradient controlled by a tipping-point mechanism. Proc. Natl. Acad. Sci. USA 2012, 109, 4668-4673.

212. Lee, J.S.; Mulkey, T.J.; Evans, M.L. Inhibition of polar calcium movement and gravitropism in roots treated with auxin-transport inhibitors. Planta 1984, 160, 536-543.

213. Lee, J.S.; Mulkey, T.J.; Evans, M.L. Gravity-induced polar transport of calcium across root tips of maize. Plant Physiol. 1983, 73, 874-876.

214. Bjorkman, T.; Leopold, A.C. Effect of inhibitors of auxin transport and of calmodulin on a gravisensing-dependent current in maize roots. Plant Physiol. 1987, 84, 847-850.

215. Lee, J.S.; Mulkey, T.J.; Evans, M.L. Reversible loss of gravitropic sensitivity in maize roots after tip application of calcium chelators. Science 1983, 220, 1375-1376.

216. Friedman, H.; Meir, S.; Rosenberger, I.; Halevy, A.H.; Kaufman, P.B.; Philosoph-Hadas, S. Inhibition of the gravitropic response of snapdragon spikes by the calcium-channel blocker lanthanum chloride. Plant Physiol. 1998, 118, 483-492.

217. Daye, S.; Biro, R.L.; Roux, S.J. Inhibition of gravitropism in oat coleoptiles by the calcium chelator, ethyleneglycol-bis-(beta-aminoethyl ether)- $N, N^{\prime}$-tetraacetic acid. Plant Physiol. 1984, 61, 449-454.

218. Biro, R.L.; Hale, C.C.; Wiegand, O.F.; Roux, S.J. Effects of chlorpromazine on gravitropism in avena coleoptiles. Ann. Bot. 1982, 50, 737-745.

219. Stinemetz, C.L.; Kuzmanoff, K.M.; Evans, M.L.; Jarrett, H.W. Correlation between calmodulin activity and gravitropic sensitivity in primary roots of maize. Plant Physiol. 1987, 84, 1337-1342.

220. Baldwin, K.L.; Strohm, A.K.; Masson, P.H. Gravity Sensing and signal transduction in vascular plant primary roots. Am. J. Bot. 2013, 100, 126-142.

221. Kleine-Vehn, J.; Ding, Z.; Jones, A.R.; Tasaka, M.; Morita, M.T.; Friml, J. Gravity-induced PIN transcytosis for polarization of auxin fluxes in gravity-sensing root cells. Proc. Natl. Acad. Sci. USA 2010, 107, 22344-22349.

222. Ottenschlager, I.; Wolff, P.; Wolverton, C.; Bhalerao, R.P.; Sandberg, G.; Ishikawa, H.; Evans, M.; Palme, K. Gravity-regulated differential auxin transport from columella to lateral root cap cells. Proc. Natl. Acad. Sci. USA 2003, 100, 2987-2991.

223. Luschnig, C.; Gaxiola, R.A.; Grisafi, P.; Fink, G.R. Eir1, a root-specific protein involved in auxin transport, is required for gravitropism in Arabidopsis thaliana. Genes Dev. 1998, 12, 2175-2187.

(C) 2013 by the authors; licensee MDPI, Basel, Switzerland. This article is an open access article distributed under the terms and conditions of the Creative Commons Attribution license (http://creativecommons.org/licenses/by/3.0/). 